\title{
Neuropilins: A New Target for Cancer Therapy
}

\author{
Camille Grandclement ${ }^{1,2,3, *}$ and Christophe Borg ${ }^{1,2,3,4}$
}

1 INSERM UMR 645, F-25020 Besançon, France; E-Mail: christophe.borg@efs.sante.fr

2 University of Franche-Comté, IFR133, F-25020 Besançon, France

3 EFS Bourgogne Franche-Comté, F-25020 Besançon, France

4 Department of Medical Oncology, CHU Besançon, F-25000 Besançon, France

* Author to whom correspondence should be addressed; E-Mail: camille.grandclement@gmail.com; Tel.: +33-3-81-61-56-15 or +33-3-81-66-93-21; Fax: +33-3-81-61-56-17.

Received: 23 February 2011; in revised form: 23 March 2011 / Accepted: 1 April 2011 /

Published: 8 April 2011

\begin{abstract}
Recent investigations highlighted strong similarities between neural crest migration during embryogenesis and metastatic processes. Indeed, some families of axon guidance molecules were also reported to participate in cancer invasion: plexins/semaphorins/neuropilins, ephrins/Eph receptors, netrin/DCC/UNC5. Neuropilins (NRPs) are transmembrane non tyrosine-kinase glycoproteins first identified as receptors for class-3 semaphorins. They are particularly involved in neural crest migration and axonal growth during development of the nervous system. Since many types of tumor and endothelial cells express NRP receptors, various soluble molecules were also found to interact with these receptors to modulate cancer progression. Among them, angiogenic factors belonging to the Vascular Endothelial Growth Factor (VEGF) family seem to be responsible for NRP-related angiogenesis. Because NRPs expression is often upregulated in cancer tissues and correlated with poor prognosis, NRPs expression might be considered as a prognostic factor. While NRP1 was intensively studied for many years and identified as an attractive angiogenesis target for cancer therapy, the NRP2 signaling pathway has just recently been studied. Although NRP genes share $44 \%$ homology, differences in their expression patterns, ligands specificities and signaling pathways were observed. Indeed, NRP2 may regulate tumor progression by several concurrent mechanisms, not only angiogenesis but lymphangiogenesis, epithelial-mesenchymal transition and metastasis. In view of their multiples functions in cancer promotion, NRPs fulfill all the criteria of a
\end{abstract}


therapeutic target for innovative anti-tumor therapies. This review focuses on NRP-specific roles in tumor progression.

Keywords: neuropilins; cancer; angiogenesis; lymphangiogenesis; targeted therapies

\section{Introduction}

Neuropilins (NRPs; previously known as A5 protein) were first identified by Takagi et al. in 1987 by immunofluorescent staining of frozen sections of Xenopus tadpole nervous system [1]. This glycoprotein of 130-140 kDa, highly conserved among vertebrates, was then isolated in the nervous developing system of a broad spectrum of animal species, such as chicken [2,3], mice [4], and rats [5,6]. While NRP1 was the first member of the NRP family to be described, NRP2 was rapidly isolated by Chen et al. in 1997, by RT-PCR and gene transfer [7].

A major distinction between these two members of the NRP family is based on their ligand specificities. NRPs were originally described as high-affinity cell-surface receptors for axon guidance molecules such as class-3 semaphorins (Sema) [6]. Indeed, NRP1 is a receptor for semaphorin-3A, 3C, 3F [5,6] while NRP2 preferentially binds Semaphorin 3B, 3C, 3D, 3F [7,8] (Figure 1).

Figure 1. Neuropilins (NRPs) and their ligands. Class-3 semaphorins bind a1/a2 sub-units (green) whereas vascular-endothelial growth factors preferentially bind b1/b2 sub-units (blue). Other growth factors such as HGF, B-FGF, TGF $\beta 1$ have been recently reported to bind both NRPs (yellow).

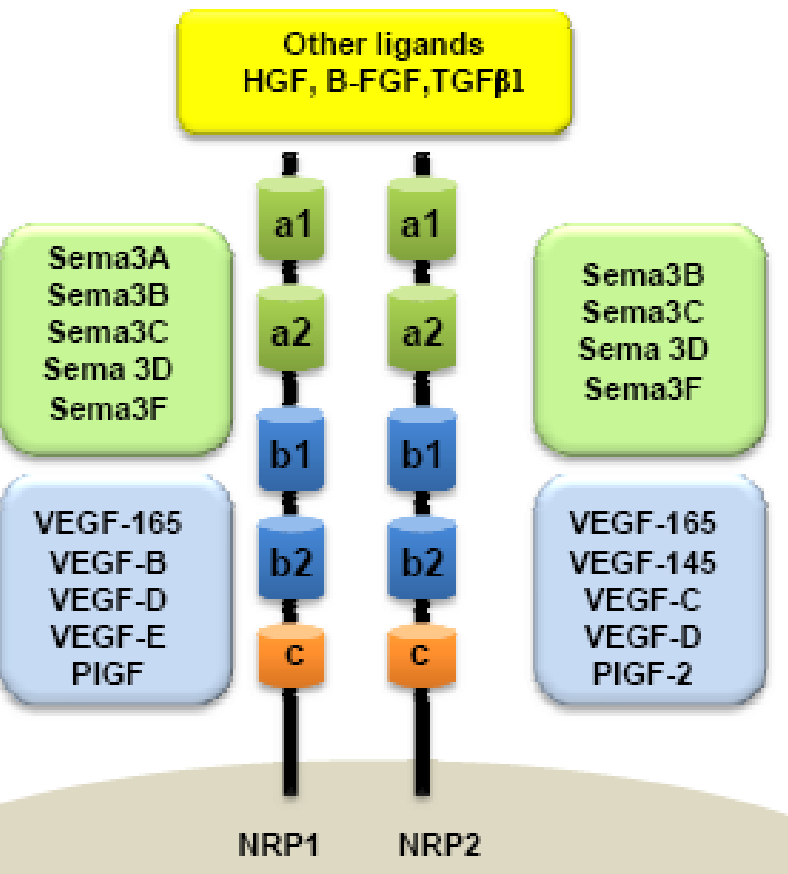


Several analyses using mutant mice lacking NRPs function subsequently conferred to semaphorin/neuropilin an essential role in axon guidance during nervous system development [8-11].

In vivo models using NRPs transgenes also suggested other essential functions of NRPs. Indeed, overexpression of NRP1 in chimeric mice generated an excess of capillaries and blood vessels, suggesting an important role of NRP1 in angiogenesis and vasculogenesis [12]. In contrast, NRP1 null-mutant embryos showed severe types of vascular defects, especially in neuronal vasculature, yolk sac vessel network organization, aortic arch development [13] and in the cardiovascular system, resulting in death of homozygous embryos at E12.5 to E13.5 [13,14]. NRP2 knock-out mice are viable suggesting that NRP2 is not essential for vascular development, unlike NRP1 [9,11]. Moreover, NRP2 homozygous mutant mice are characterized by abnormal lymphatic and capillary development suggesting a selective requirement for NRP2 in the formation of lymphatic vessels [15]. However, double knock-out of NRPs genes (NRP1 ${ }^{--} \mathrm{NRP}^{-/}$) constitutes the most severe phenotype observed, impairing any blood vessel development and causing earliest death in utero at E8.5 [14].

Because Vascular Endothelial Growth Factor (VEGF) plays a central role in the development of vascular network, interactions between NRPs and VEGF were rapidly considered. NRPs were indeed found to be receptors for several members of the VEGF family. NRP1 can effectively bind VEGF ${ }_{165}$, PIGF-2 (Placenta Growth Factor), VEGF-B, VEGF-C, VEGF-D and VEGF-E [16-21], whereas NRP2 is a receptor for $\mathrm{VEGF}_{145}, \mathrm{VEGF}_{165}$, PIGF-2 [18,22], VEGF-C [20,22], and VEGF-D [20]. NRPs are also reported to bind diverse heparin-growth factors, such as FGF (Fibroblast Growth Factor) and HGF (Hepatocyte Growth Factor) [23,24] (Figure 1).

\section{NRPs: Structural Particularities}

In humans, NRP1 and NRP2 genes map to two different chromosomes: Chromosomes 10p12 and 2q34, respectively [25]. Although NRPs share only 44\% homology in their amino acid sequences, some similarities to known proteins can be observed in their structure. NRPs are composed of an extracellular domain, transmembrane domain and a short intracellular domain. Indeed, the extracellular domain is composed of two Complement Binding motifs (CUB), homologous to the C1r and C1s complement components (named domains a1 and a2), two domains b1 and b2 homologous to the coagulation factors V and VIII and one third domain, c, homologous to the meprim domain sharing a tyrosine phosphatase activity $\mu[4,26]$. a1/a2 domains are responsible for semaphorin binding, whereas b1/b2 are suggested for both VEGF and semaphorin binding. c-domain is involved in dimerization of the receptor [8] (Figure 1). Because NRPs have a short intracellular domain of only 40 amino acids, it was assumed that they cannot transmit any signal on their own.

\subsection{Isoforms}

Both NRPs genes are composed of 17 exons. Contrary to NRP1, NRP2 is expressed as several alternatively spliced forms. In particularly, two isoforms of NRP2, NRP2a and NRP2b, that arise by alternative splicing, have been described subsequently in mouse [7] and humans [25]. Divergences between NRP2a and NRP2b are principally observed in the linker between transmembrane and cytoplasmic domains. NRP2 subisoforms were subsequently described by Chen [7] and Rossignol [25]. Insertions of 17 or 22 amino acids after amino acid 809 are described for NRP2a (NRP2a (17), 
$\left.\mathrm{NRP} 2 \mathrm{a}_{(22)}\right)$ whereas NRP2b is characterized by insertions of 0 or 5 amino acids after amino acid 808 $\left(\mathrm{NRP}_{2} \mathrm{~b}_{(0)}, \mathrm{NRP} 2 \mathrm{~b}_{(5)}\right.$ ) (Figure 2). NRP2a seems to be closer to NRP1 (44\% homology) than NRP2b (11\%) [25].

Figure 2. NRP2 transcript variants encode distinct isoforms.



\subsection{Soluble Forms}

Two soluble forms of NRP1 ( $s_{11} \mathrm{NRP} 1$ and $\left.\mathrm{s}_{12} \mathrm{NRP} 1\right)$ and one of NRP2 $\left({ }_{\mathrm{s}} \mathrm{NRP} 2\right)$ were cloned by Rossignol and collaborators [25]. Later, two novel soluble forms of NRP1, sIIIRP1 and ${ }_{\text {sIV NRPI were }}$ characterized [27]. While these soluble isoforms have conserved their extracellular domains responsible for ligand binding, c-domain, transmembrane and intracellular domains were lacking. Moreover, Gagnon et al., reported that $\mathrm{s}_{11} \mathrm{NRP} 1$ is capable of tumor cell apoptosis by antagonizing VEGF binding, suggesting that sNRPs and NRPs have opposite functions [28].

\section{Neuropilins Expression Pattern}

\subsection{Embryogenesis}

First reports limited NRPs expression in the nervous developing tissues [1,2,4,7,29]. Indeed, Chen et al. observed increased NRP2 expression in most components of the developing nervous system including spinal cord, sympathetic ganglia, olfactory system, neocortex, hippocamp [7].

NRP were also found in development of many non neuronal tissues such as bones, several muscles, intestinal epithelium, kidney, lung, dorsal aorta [7]. Moreover, knock-out studies have suggested an important role of the NRPs in the development of the vascular system during embryogenesis. While NRP1 is preferentially expressed in arteries during embryonic development, NRP2 is required for the formation of veins and lymphatic vessels $[12,15]$.

\subsection{Immune System}

NRP1 was rapidly identified on various immune cells such as some subpopulations of $\mathrm{T}$ lymphocytes and on dendritic cells (DC) in vitro and in vivo [30]. In this immune context, NRP1 
enhances cell-cell interaction, especially in mediating DC-induced proliferation of resting $\mathrm{T}$ cells [30]. NRP1 is expressed by CD4+CD25+ murine regulatory $\mathrm{T}$ cells but not by naïve $\mathrm{T}$ cells [31]. When expressed on murine $\mathrm{T}$ reg cells, NRP1 inhibits $\mathrm{T}$ cell proliferation [32]. However, Milpied et al. observed in 2009 that NRP1 expression on murine T reg could not be extended in human [33]. On the other hand, NRP2's contribution in the immune system was only very recently studied. NRP2 is expressed on a polysialylated form on mature human DC [34]. Because polysialylation of proteins is a very rare phenomenon, its role has not been extensively characterized. However, polysialylation of NRP2 on DC seems to be essential for CCL21-dependent DC migration (CCL21: Chemokine C-C motif Ligand 21) to the lymph nodes during immune response [35,36].

\subsection{Human Tumors}

The contribution of NRPs in angiogenesis prompted the investigation of NRP's role in oncogenesis. Besides the presence of NRPs on tumor-associated vessels, authors have reported the wide expression of NRPs among different human tumors, suggesting a potential role of this molecular network in cancer progression. In 1998, Soker et al. isolated NRP1 from endothelial cells and tumor tissues [21]. Indeed, NRPs expression is not restricted in intra-tumoral vessels, but a large variety of cancer cells are reported to express one or both NRPs. Moreover, NRPs are often the only VEGF-receptors expressed by tumor cells [37,38], conferring an essential role of these glycoproteins as growth factor receptors. Although NRP1 is expressed by a large variety of tumors, even less is known concerning the expression of NRP2 (Table 1). However, NRP2 expression was found in osteosarcomas [39], melanomas [40], lung cancers [41,42], brain tumors [43,44] colon cancers [45], pancreatic cancers [46-49], breast cancers [50], myeloid leukemias [51], salivary adenoid cystic carcinomas (SACCs) [52], infantile hemangiomas [53], ovarian neoplasms [54] and bladder cancers [55] (Table 1).

Table 1. Neuropilins (NRPs) expression in cancer cells.

\begin{tabular}{|c|c|c|l|}
\hline Tumors & NRP1 & NRP2 & \multicolumn{1}{|c|}{ References } \\
\hline Brain tumors & & & \\
\hline Astrocytomas & $\mathrm{x}$ & $\mathrm{ND}$ & Ding H et al., 2000 [56] \\
\hline Neuroblastomas & $\mathrm{x}$ & $\mathrm{x}$ & Fakhari M et al. [44] \\
\hline \multirow{2}{*}{ Gliomas } & $\mathrm{x}$ & $\mathrm{x}$ & Rieger J et al., 2003 [43] \\
\hline Glioblastomas & $\mathrm{x}$ & $\mathrm{ND}$ & Osada H et al., 2004 [54] \\
\hline Pituitary tumors & $\mathrm{x}$ & $\mathrm{ND}$ & Broholm H et al., 2004 [57] \\
\hline Digestive tumors & $\mathrm{x}$ & $\mathrm{ND}$ & Onofri C et al., 2006 [58] \\
\hline \multirow{2}{*}{ Endocrine pancreatic tumors } & $\mathrm{ND}$ & $\mathrm{x}$ & Cohen T et al., 2002 [47] \\
\hline \multirow{3}{*}{ Pancreatic adenocarcinomas } & $\mathrm{x}$ & $\mathrm{ND}$ & Parikh AA et al., 2003 [59] \\
\cline { 2 - 4 } & $\mathrm{x}$ & $\mathrm{x}$ & Fukahi K et al., 2004 [48] \\
\cline { 2 - 4 } & $\mathrm{x}$ & $\mathrm{x}$ & Li M et al., 2004 [49] \\
\cline { 2 - 4 } & $\mathrm{x}$ & $\mathrm{x}$ & Feurino LW et al., 2007 [60] \\
\cline { 2 - 4 } & $\mathrm{x}$ & $\mathrm{ND}$ & Akagi M et al., 2003 [61] \\
\hline \multirow{2}{*}{ Gastric cancer } & $\mathrm{x}$ & $\mathrm{ND}$ & Hansel DE et al., 2004 [62] \\
\hline
\end{tabular}


Table 1. Cont.

\begin{tabular}{|c|c|c|c|}
\hline \multirow{3}{*}{ Colon cancer } & $\mathrm{x}$ & ND & Parikh AA et al., 2004 [63] \\
\hline & $\mathrm{x}$ & ND & Ochiumi T et al., 2006 [64] \\
\hline & $\mathrm{ND}$ & $\mathrm{x}$ & Gray MJ et al., 2008 [45] \\
\hline \multicolumn{4}{|l|}{ Leukemias } \\
\hline \multirow{4}{*}{ Acute Myeloid Leukemia (AML) } & $\mathrm{x}$ & ND & Kreuter M et al., 2006 [65] \\
\hline & $\mathrm{x}$ & ND & Kreuter M et al., 2007 [66] \\
\hline & $\mathrm{x}$ & $\mathrm{x}$ & Vales A et al., 2007 [51] \\
\hline & $\mathrm{x}$ & ND & Lu L et al., 2007 [67] \\
\hline Chronic lymphocytic leukemia B & $\mathrm{x}$ & ND & Nowakowski GS et al., 2008 [68] \\
\hline \multicolumn{4}{|l|}{ Other solid tumors } \\
\hline \multirow{2}{*}{ Breast cancers } & $\mathrm{x}$ & ND & Stephenson JM et al., 2002 [69] \\
\hline & $\mathrm{x}$ & ND & Ghosh M et al., 2008 [70] \\
\hline \multirow{2}{*}{ NSCLC } & $\mathrm{x}$ & $\mathrm{x}$ & Kawakami T et al., 2002 [41] \\
\hline & $\mathrm{x}$ & $\mathrm{x}$ & Lantuejoul S et al., 2003 [71] \\
\hline Lung cancers & $\mathrm{x}$ & $\mathrm{x}$ & Tomizawa et al., 2001 [42] \\
\hline \multirow{2}{*}{ Melanomas } & $\mathrm{x}$ & $\mathrm{x}$ & Lacal PM et al., 2000 [40] \\
\hline & $\mathrm{x}$ & ND & Straume O et al., 2003 [72] \\
\hline \multirow{2}{*}{ Prostate cancers } & $\mathrm{x}$ & ND & Latil A et al., 2000 [73] \\
\hline & $\mathrm{x}$ & $\mathrm{ND}$ & Vanveldhuizen PJ et al., 2003 [74] \\
\hline $\begin{array}{c}\text { Laryngeal carcinomas and } \\
\text { papillomas }\end{array}$ & $\mathrm{x}$ & ND & Zhang S et al., 2006 [75] \\
\hline $\begin{array}{c}\text { Salivary adenoid cystic } \\
\text { carcinoma }\end{array}$ & ND & $\mathrm{x}$ & Cai Y et al., 2010 [52] \\
\hline Infantile hemangiomas & ND & $\mathrm{x}$ & Calicchio ML et al., 2009 [53] \\
\hline \multirow{3}{*}{ Ovarian carcinomas } & $\mathrm{x}$ & ND & Hall GH et al., 2005 [76] \\
\hline & $\mathrm{x}$ & $\mathrm{x}$ & Osada R et al., 2006 [54] \\
\hline & $\mathrm{x}$ & ND & Baba T et al., 2007 [77] \\
\hline Bladder cancers & $\mathrm{ND}$ & $\mathrm{x}$ & Sanchez Carbayo M et al., 2003 [55] \\
\hline Osteosarcomas & $\mathrm{ND}$ & $\mathrm{x}$ & Handa et al., 2000 [39] \\
\hline
\end{tabular}

\subsection{Regulation of Neuropilins Expression}

NRP1 expression was promoted by hypoxia in several models [78-80] and by ischemia in rats [81], and in mice [82]. Moreover, several growth factors and inflammatory cytokines are involved in NRP regulation too: In pancreatic cancer cells, IL-6 enhances NRP1 expression [60] whereas IL-8 increases NRP2 expression via activation of ERK1/2 pathway [83]. TNF $\alpha$ was shown to upregulate VEGFR2 and NRP1 in human vascular endothelial cells [84]. While TGF- $\beta 1$ and IL- $1 \beta$ inhibit NRP1 expression, TGF- $\beta 1$ stimulates NRP2 expression in human proximal tubular cells through activation of MEK1/2-ERK1/2 pathway [85]. Oncostatin M activates both NRP1 and NRP2 expression [85].

\section{Neuropilins Role in Oncogenesis}

NRPs display a short intracytoplasmic tail of 40 amino acids which does not contain any kinase domain, leading to the suggestion that neuropilins can not directly transmit intracellular signals. This 
led to the proposal that hetero-dimerization with other membrane receptors are required to mediate neuropilin-downstream signaling.

\subsection{Interactions with Plexins/Semaphorins}

Semaphorins (Sema, also known as collapsins) are subdivided into eight classes, on the basis of structural similarities. Class 1 and 2 constitutes invertebrate semaphorins, whereas classes 3 to 7 comprise vertebrate semaphorins [86]. All semaphorins are characterized by an identical N-terminal 500-amino-acid-long sema domain, which is essential for semaphorin signaling. The structure of the sema domain is a seven-blade $\beta$-propeller fold which presented similarities with extracellular domain of $\alpha$-integrins [87]. Next to the sema domain, semaphorins contain several distinct domains in their structure, such as a plexin-semaphorin-integrin domain (PSI), an immunoglobulin-like, a thrombospondin and a basic-C domains [88]. Class-3 semaphorins are secreted semaphorins characterized by a basic-charged domain at the C-terminus. Class 4-7 semaphorins are membrane-bound semaphorins which are characterized by thrombospondin repeats (class-5 semaphorins) or glycophosphatidylinositol (GPI) anchor (class-7 semaphorins). Membrane-bound semaphorins can be cleaved into soluble forms through proteolytic degradation [89]. Two high affinity receptors have been identified for semaphorins: Plexins and Neuropilins. Various studies indicate that plexins are required for class 3 semaphorin/neuropilins signaling pathway during both embryonic development and tumorigenesis.

Plexin family is the first class of co-receptor identified. Plexins have been identified like NRPs, from immunostaining of Xenopus tadpoles nervous tissue [1]. While plexins play an important role in axon guidance [90] by forming complexes with NRPs [91,92], plexins have been identified on various tumor tissues, suggesting a role in tumorigenesis [93,94]. Nine members of the plexin family have been identified, subdivided into four subfamilies comprising four type-A plexins, three type-B plexins, plexin $\mathrm{C} 1$ and plexin D1. Plexins can tranduce intracellular signals through activation of Rho-like GTPases, such as Rnd1 for plexin A1 and Rac1 for plexin B1 [95-97]. Moreover, type B plexins contain a binding site for a PDZ domain in the C-terminal domain [98-100]. The extracellular domains of all plexins are characterized by the presence of a sema domain, and by the presence of PSI and glycine-proline (G-P)rich motifs [86]. Membrane-bound semaphorins can directly bind to the plexins, whereas secreted semaphorins such as class-3 semaphorins required NRPs as co-receptor to mediate the signal [86].

Like type-B plexins, NRPs contain a binding site for PDZ domains in the C-terminal domain. Indeed, the PDZ domain of NIP, also called GIPC (GAIP interacting protein at the C terminus), is thought to be implicated in interaction with NRPs and plexins, activating small GTPase-activating proteins [101]. In particular, the last three amino-acids SEA of the C-terminal sequence of NRPs seem to be responsible for interaction with G-interacting proteins [101] (Figure 3).

Semaphorins are reported to be very often down-regulated or mutated in human cancers, allowing massive VEGF/NRPs interactions. Because semaphorins are frequently inactivated by allele loss or promoter methylation, they have been rapidly considered to function as a TSG (tumor suppressor gene). Indeed, deletions occur in the region $3 \mathrm{p} 21.3$ of the short arm of chromosome 3, a region encoding for Sema3B and Sema3F in various cancers, including lung cancer and even ovarian cancer [102-104]. Moreover, semaphorin promoter hypermethylation and various mutations occur in lung and breast cancers [42,105-108]. 
Figure 3. NRPs cooperate with class 3 semaphorins and plexins in endothelial and cancer cells.

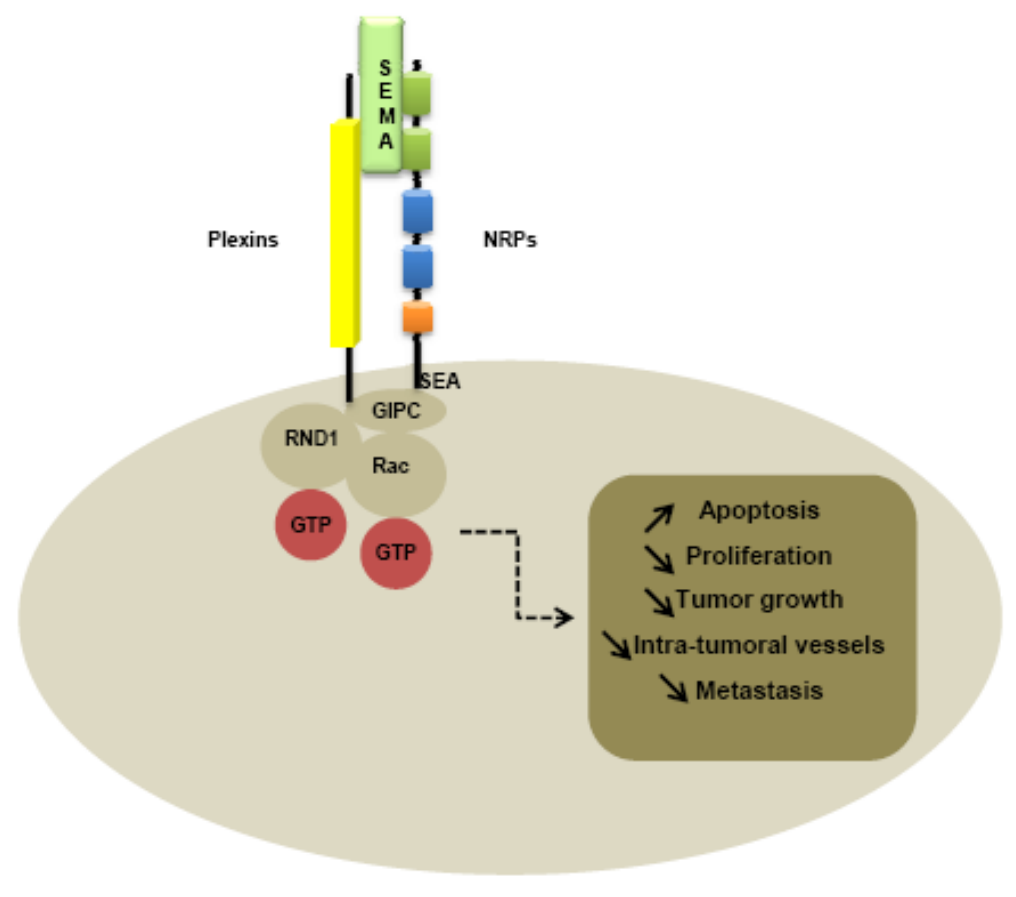

\subsubsection{Semaphorin $3 \mathrm{~A}$}

First, Bagnard et al. reported that Semaphorin 3A (Sema3A) mediates cell repulsion and can even induce cell death in a neuroectodermal progenitor cell line, both effects depending on interactions with NRP1 [109].When Sema3A is added to the culture medium of Human Umbilical Vein Endothelial Cells (HUVEC) cells for $48 \mathrm{~h}$ with VEGF $_{165}$, cell survival decreases. NRP1 is implicated in this Sema3A-mediated apoptosis [110]. Moreover, Sema3A has been implicated directly in Fas-mediated apoptosis in a recent study [111]. After a stimulation of leukemic T cells by Sema3A, Fas localizes into the lipid rafts and sensitizes these T cells to FasL-mediated apoptosis [111] (Table 2).

Table 2. Class 3 semaphorins expression and function in tumor cells.

\begin{tabular}{|l|l|l|l|}
\hline Semaphorins & \multicolumn{1}{|c|}{ Cells } & \multicolumn{1}{|c|}{ Activity } & \multicolumn{1}{c|}{ References } \\
\hline \multirow{5}{*}{ Sema3A } & $\begin{array}{l}\text { Neural progenitor } \\
\text { cells }\end{array}$ & Induction of cell repulsion and cell death & Bagnard D, 2001[109] \\
\cline { 2 - 4 } & Endothelial cells & Induction of apoptosis & $\begin{array}{l}\text { Guttmann-Raviv N, } \\
\text { 2007 [110] }\end{array}$ \\
\cline { 2 - 4 } & Leukemic T cells & Relocalization of Fas into the lipid raft & Moretti S, 2008 [111] \\
\cline { 2 - 4 } & Breast cancer cells & $\begin{array}{l}\text { Inhibition of tumor growth, of intra-tumor } \\
\text { vasculature }\end{array}$ & Kigel B, 2008 [112] \\
\cline { 2 - 4 } & Breast tumor cells & $\begin{array}{l}\text { Inhibition of cell migration, increase of } \\
\text { alpha2beta1 integrin level }\end{array}$ & Pan H, 2009 [127] \\
\hline \multirow{4}{*}{$\begin{array}{l}\text { murine pancreatic } \\
\text { cells }\end{array}$} & $\begin{array}{l}\text { Inhibition of tumor growth, of intra-tumor } \\
\text { vasculature }\end{array}$ & Maione F, 2009 [113] \\
\cline { 2 - 4 } & $\begin{array}{l}\text { murine mammary } \\
\text { carcinoma cells }\end{array}$ & $\begin{array}{l}\text { Inhibition of tumor growth, of intra-tumor } \\
\text { vasculature and metastasis }\end{array}$ & Casazza A, 2011 [114] \\
\hline
\end{tabular}


Table 2. Cont.

\begin{tabular}{|c|c|c|c|}
\hline Semaphorins & Cells & Activity & References \\
\hline \multirow{4}{*}{ Sema3B } & Lung cancer cells & $\begin{array}{l}\text { Inhibition of growth and induction of } \\
\text { apoptosis }\end{array}$ & Tomizawa, 2001 [42] \\
\hline & \begin{tabular}{|l|} 
Ovarian \\
adenocarcinoma cell \\
line \\
\end{tabular} & $\begin{array}{l}\text { Diminution of tumorigenicity in xenografts } \\
\text { experiments, diminution of colony formation } \\
\text { and cell proliferation }\end{array}$ & Tse C, 2002 [115] \\
\hline & $\begin{array}{l}\text { Lung and breast } \\
\text { cancer cells }\end{array}$ & Induction of apoptosis & \begin{tabular}{|l} 
Castro-Rivera E, \\
2004, 2008 [116, 117]
\end{tabular} \\
\hline & Breast cancer cells & $\begin{array}{l}\text { NRP1-sema3B interactions increase IL8 } \\
\text { production in tumor cells, promoting } \\
\text { invasion and metastasis }\end{array}$ & Rolny C, 2008 [118] \\
\hline Sema3D & Breast cancer cells & Inhibition of tumor progression & Kigel B, 2008 [112] \\
\hline Sema3E & Breast cancer cells & Increase of tumor growth, metastasis & $\begin{array}{l}\text { Christensen C, } 2005 \\
{[126]}\end{array}$ \\
\hline \multirow{9}{*}{ Sema3F } & Lung cancer cells & Role in cell motility and cell adhesion & $\begin{array}{l}\text { Brambilla E, } 2000 \\
{[119]}\end{array}$ \\
\hline & \begin{tabular}{|l|} 
Small cell lung \\
cancer cells, ovarian \\
adenocarcinoma \\
\end{tabular} & $\begin{array}{l}\text { Diminution of tumorigenicity in xenografts } \\
\text { experiments, induction of apoptosis }\end{array}$ & Xiang R, 2002 [120] \\
\hline & Breast cancer cells & Inhibition of cell migration & Nasarre P, 2003 [128] \\
\hline & $\begin{array}{l}\text { Endothelial, renal } \\
\text { cancer cells }\end{array}$ & $\begin{array}{l}\text { Inhibition of cell proliferation, inhibition of } \\
\text { angiogenesis in vivo }\end{array}$ & Kessler O, 2004 [122] \\
\hline & Melanomas & $\begin{array}{l}\text { Inhibition of metastasis, of intra-tumor } \\
\text { vessels and induction of large areas of } \\
\text { apoptosis in vivo }\end{array}$ & $\begin{array}{l}\text { Bielenberg BR, } \\
\text { 2004[123] }\end{array}$ \\
\hline & Breast cancer cells & $\begin{array}{l}\text { Induction of cell repulsion, inhibition of cell } \\
\text { contacts and proliferation }\end{array}$ & Nasarre P, 2005 [125] \\
\hline & Lung cancer cells & Enhances survival in xenografts experiment & Kusy S, 2005 [121] \\
\hline & Melanomas & Inhibition of cell proliferation & $\begin{array}{l}\text { Chabbert-de Ponnat I, } \\
2006 \text { [124] }\end{array}$ \\
\hline & $\begin{array}{l}\text { Breast and } \\
\text { melanoma cancer } \\
\text { cells }\end{array}$ & Inhibition of tumor progression in vivo & Kigel B, 2008 [112] \\
\hline
\end{tabular}

In another study, Kigel and colleagues transfected breast cancer cells expressing NRP1 and-or NRP2 with each semaphorin to analyze their role in tumor progression in xenograft experiments [112]. Sema3A, sema3D, sema3E and sema3G overexpression in breast cancer cells significantly inhibits the development of tumor in xenograft models and decreases the number of intra-tumor blood vessels, suggesting an anti-angiogenic role of these molecules [112]. In this model, the anti-tumor effect of each of the semaphorins correlated very well with the expression of the related receptor on tumor cells [112]. Furthermore, in a very recent study using multiple murine models of tumorigenesis, Maione and collaborators showed that inhibition of sema3A in the later stages of carcinogenesis is responsible for enhanced angiogenesis and tumor progression [113]. By contrast, restoration of Sema3A expression in these cells normalizes intra-tumor vasculature, indicating that Sema3A could be used as a potential 
anti-angiogenic agent [113]. In another recent study, Sema3A role in tumor progression and in tumor angiogenesis was evaluated using three experimental approaches, using different systems for the release of the semaphorins [114]. In all experiments, NRP1 seems to be essential for Sema3Amediated inhibition of tumor growth, angiogenesis and metastasis [114] (Table 2).

\subsubsection{Semaphorin 3B}

In lung and ovarian cancer cells, Semaphorin 3B (Sema3B) expression decreases colony formation, proliferation, and even tumorigenicity in murine xenograft experiments [42,115]. Similarly, Sema3B was shown to induce apoptosis in cancer cells, in particularly by blocking VEGF-binding to the NRPs [116,117] (Table 2). Moreover, NRP1-Sema3B interactions induce high level of IL-8 in tumor cells, leading to a massive monocyte/macrophage recruitment, promoting invasion and metastasis formation [118]. As a consequence, when sema3B is inhibited using RNA interference and IL-8 neutralized with blocking monoclonal antibodies, a decrease of invasion and metastasis is observed in murine xenograft experiments [118] (Table 2).

\subsubsection{Semaphorin 3F}

First observations that Semaphorin 3F (Sema3F) might have a role in cell motility and cell invasion was suggested by Brambilla and colleagues, in lung cancer cells [119]. Then, some studies reported that Sema3F can even induce apoptosis in cancer cells as well as tumor suppression in various xenograft experiments. Indeed, transfection of Sema3F in the murine fibrosarcoma cell line A9 and in HEY ovarian cell line suppresses tumor formation in nude mice, whereas no effect was observed after transfection of Sema3F in the small cell lung cancer cell line GLC45 [120]. When nude rats were orthotopically implanted with lung cancer cells transfected or not with Sema3F gene, all animals injected with cells expressing sema3f survived to 100 days whereas all the other rats died [121] (Table 2).

A role of Sema3F in tumor angiogenesis was then suggested. Implantation of BHK-21 (Baby Hamster Kidney-21) cells transfected with Sema3F concomitantly with cells producing VEGF-165 inhibited tumor-related angiogenesis in mice whereas no effect on angiogenesis was observed when BHK-21 cells transfected with empty vector were implanted with the same VEGF-165 producing cells [122]. Moreover, Sema3F transfection in the renal cell line HEK293 induced smaller tumors and a poorly-vascularized phenotype in xenograft experiments [122]. As a consequence, Sema3F and VEGF were rapidly considered to generate opposite activities. In fact, in highly metastatic melanoma cells, Sema3F completely inhibits metastasis in vivo and decreased the number of intra-tumor vessels, suggesting that Sema3F has huge potential in anti-angiogenic and anti-metastasis therapies [123] (Table 2). In addition, Sema3F can represent a powerful inhibitor of melanoma cell proliferation through its relation with NRP receptors [124].

Moreover, Sema3F blocks cell attachment and spreading in MCF7 and C100 breast cell lines, this effect depending on its interactions either with NRP1 or NRP2 [125] (Table 2). 


\subsubsection{Semaphorin $3 E$}

Although most class 3 semaphorins are considered to be TSG, it appears that others support opposite activities. Indeed, Semaphorin 3E (Sema3E) is described as an enhancer of tumor growth and metastasis in vitro and in vivo in xenograft experiments using breast cancer cells [126] (Table 2).

\subsection{Cooperation with Growth Factor Receptors}

\subsubsection{VEGFRs}

Further investigations of neuropilin-dependent molecular pathways suggested that neuropilins contribute to tumor growth and angiogenesis through their cooperation with both VEGFR receptors, VEGFR1 and VEGFR2 (Figure 4).

Figure 4. NRPs interactions with growth factor receptors.



First, Soker et al. reported that coexpression of NRP1 and VEGFR2 on porcine aortic endothelial cells enhances at least four-times the VEGF binding to VEGFR2 and in this way modulates downstream signaling and biological responses [21]. Later, Biacore analysis revealed that NRP1 interacts with both VEGFR1 and VEGFR2 [19]. Moreover, NRP1 enhances binding of VEGF to these two high affinity receptors. Similar results were obtained for NRP2. Indeed, co-immunoprecipitation studies revealed that NRP2 and VEGFR1 associate with each other to tranduce intracellular 
signals [129]. NRP2 enhances VEGFR1 phosphorylation and subsequently activates multiple intracellular pathways like extracellular signal-regulated kinase (ERK) or phosphatidylinositol 3-kinase (PI3K) pathways in colorectal cancer cells and pancreatic adenocarcinoma cells [45,46]. (Table 3) While NRP1 implication in the angiogenesis process has now considerable evidence, NRP2 appears to regulate lymphangiogenesis and metastatic processes. Indeed, NRP2 homozygous mutant mice are characterized by abnormal lymphatic and capillaries development proposing a selective requirement for NRP2 in the formation of lymphatic vessels [15]. Karpänen et al. propose that NRP2 contributes to lymphangiogenesis and metastastatic processes through direct interactions with VEGF-C, VEGF-D and VEGFR3 [20]. NRP2 increases VEGF-A and VEGF-C-induced survival and migration of endothelial cells [130]. Moreover, Caunt et al. recently reported that NRP2 blocking with a monoclonal antibody (anti-NRP2 ${ }^{\mathrm{B}}$ ) leads to a reduction of VEGFC-mediated migration of Lymphatic Endothelial cells (LEC) in vitro and to an inhibition of lymphangiogenesis in vivo [131]. Metastasis formation is found to be subsequently reduced in mice in xenograft models after anti-NRP2 ${ }^{\mathrm{B}}$ treatment [131]. Double-heterozygous $n r p 2^{+/-}$vegfr $2^{+/-}$mice have normal lymphatic development unlike double-heterozygous $n r p 2^{+/-}$vegfr $3^{+/-}$mice, indicating that Nrp2 partners with VEGFR3 to modulate lymphatic vessel sprouting and lymphangiogenesis [132]. Finally, another recently published study has reinforced the essential role of NRP2 in lymphangiogenesis process. Indeed, NRP2 knockdown by RNA interference improves corneal graft survival by suppressing lymphangiogenesis in vascular beds in a murine model of corneal transplantation [133] (Table 3).

Table 3. NRPs interactions with growth factor receptors.

\begin{tabular}{|c|c|c|c|}
\hline Complexes & Cells & Activity & References \\
\hline \multirow{3}{*}{ NRP/VEGFR1 } & Biacore analysis & NRP1 associates with VEGFR1 and VEGFR2 & $\begin{array}{l}\text { Fuh et al., } \\
2000 \text { [19] }\end{array}$ \\
\hline & $\begin{array}{l}\text { Endothelial Porcine } \\
\text { Aortic Endothelial } \\
\text { (PAE) cells }\end{array}$ & NRP2 co-immunoprecipitates with VEGFR1 & $\begin{array}{l}\text { Gluzman- } \\
\text { Poltorak et } \\
\text { al., 2001 } \\
{[129]}\end{array}$ \\
\hline & Colorectal cancer cells & $\begin{array}{l}\text { NRP2 enhances VEGFR1 phosphorylation, } \\
\text { migration, invasion in tumor cells through } \\
\text { PI3K and ERK activation. Targeting NRP2 } \\
\text { with shRNA reduces tumor growth, metastasis } \\
\text { formation in xenograft experiments. }\end{array}$ & $\begin{array}{l}\text { Gray et al., } \\
2008 \text { [45] }\end{array}$ \\
\hline & $\begin{array}{l}\text { Pancreatic } \\
\text { Adenocarcinoma } \\
\text { cancer cells }\end{array}$ & $\begin{array}{l}\text { NRP2 enhances VEGFR1 phosphorylation, } \\
\text { migration, invasion in tumor cells through } \\
\text { PI3K and ERK activation. Reduced NRP-2 } \\
\text { expression decreases migration, invasion, and } \\
\text { anchorage-independent growth. Targeting } \\
\text { NRP2 with shRNA reduces tumor growth, } \\
\text { tumor vasculature and metastasis formation in } \\
\text { xenograft experiments. }\end{array}$ & $\begin{array}{l}\text { Dallas et al., } \\
2008[46]\end{array}$ \\
\hline
\end{tabular}


Table 3. Cont.

\begin{tabular}{|c|c|c|c|}
\hline Complexes & Cells & Activity & References \\
\hline \multirow{4}{*}{ NRP/VEGFR2 } & $\begin{array}{l}\text { Endothelial Porcine } \\
\text { Aortic Endothelial } \\
\text { (PAE) cells }\end{array}$ & $\begin{array}{l}\text { NRP1 enhances the binding of VEGF to } \\
\text { VEGFR2 }\end{array}$ & $\begin{array}{l}\text { Soker } \text { et al., } \\
1998[21]\end{array}$ \\
\hline & Biacore analysis & NRP1 associates with VEGFR1 and VEGFR2 & $\begin{array}{l}\text { Fuh et al., } \\
2000[19] \\
\end{array}$ \\
\hline & $\begin{array}{l}\text { 293T, PAE, human } \\
\text { microvascular } \\
\text { endothelial cells }\end{array}$ & $\begin{array}{l}\text { NRP2 interacts with VEGFR2 and VEGFR3 } \\
\text { and enhances their activation. NRP2 } \\
\text { overexpression enhances VEGF-A and } \\
\text { VEGF-C induced survival and migration of } \\
\text { human endothelial cells. }\end{array}$ & $\begin{array}{l}\text { Favier et al., } \\
2006[130]\end{array}$ \\
\hline & $\begin{array}{l}\text { Lymphatic endothelial } \\
\text { cells }\end{array}$ & $\begin{array}{l}\text { NRP2 interacts with VEGFR2 and VEGFR3, } \\
\text { enhances their phosphorylation and activation. }\end{array}$ & $\begin{array}{l}\text { Caunt et al., } \\
2008[131]\end{array}$ \\
\hline \multirow{3}{*}{ NRP/VEGFR3 } & $\begin{array}{l}\text { Lymphatic endothelial } \\
\text { cells and transfected } \\
293 \mathrm{~T}\end{array}$ & $\begin{array}{l}\text { NRP2 interacts with VEGFR3 in co- } \\
\text { immunoprecipitation studies. }\end{array}$ & $\begin{array}{l}\text { Karpänen et } \\
\text { al., } 2006 \text { [20] }\end{array}$ \\
\hline & $\begin{array}{l}\text { 293T, PAE, human } \\
\text { microvascular } \\
\text { endothelial cells }\end{array}$ & $\begin{array}{l}\text { NRP2 interacts with VEGFR2 and VEGFR3 } \\
\text { and enhances their activation. NRP2 } \\
\text { overexpression enhances VEGF-A and } \\
\text { VEGF-C induced survival and migration of } \\
\text { human endothelial cells. }\end{array}$ & $\begin{array}{l}\text { Favier et al., } \\
2006[130]\end{array}$ \\
\hline & $\begin{array}{l}\text { Lymphatic endothelial } \\
\text { cells }\end{array}$ & $\begin{array}{l}\text { NRP2 interacts with VEGFR2 and VEGFR3, } \\
\text { enhances their phosphorylation and activation. }\end{array}$ & $\begin{array}{l}\text { Caunt et al., } \\
2008[131]\end{array}$ \\
\hline \multirow{3}{*}{ NRP/c-met } & HUVEC & $\begin{array}{l}\text { HGF binds NRP1 and NRP2. NRP1 and } \\
\text { NRP2 enhance c-met phosphorylation and } \\
\text { migration through ERK activation. }\end{array}$ & $\begin{array}{l}\text { Sulpice } \text { et al., } \\
2008[24]\end{array}$ \\
\hline & Glioma & $\begin{array}{l}\text { NRP1 promotes glioma progression through } \\
\text { activation of HGF/SF autocrine pathway and } \\
\text { ERK pathway activation. }\end{array}$ & $\begin{array}{l}\text { Hu B et al., } \\
2007 \text { [137] }\end{array}$ \\
\hline & Pancreatic cancer cells & $\begin{array}{l}\text { NRP1 interacts with c-met, promoting } \\
\text { invasion through ERK and p38MAPK } \\
\text { activation. }\end{array}$ & $\begin{array}{l}\text { Matsushita et } \\
\text { al., } 2007 \\
{[138]}\end{array}$ \\
\hline \multirow[t]{3}{*}{ NRP/TGFR } & Stromal fibroblasts & $\begin{array}{l}\text { NRP1 enhances Smad activation and induces } \\
\text { a myofibroblast phenotype. }\end{array}$ & $\begin{array}{l}\text { Cao et al., } \\
2010[142]\end{array}$ \\
\hline & Breast cancer cells & $\begin{array}{l}\text { NRP1 and NRP2 associate with TGFRI and } \\
\text { TGFRII and enhance Smad } 2 / 3 \\
\text { phosphorylation. }\end{array}$ & $\begin{array}{l}\text { Glinka et al., } \\
2010[140]\end{array}$ \\
\hline & Colorectal cancer cells & $\begin{array}{l}\text { NRP2 interacts with TGFRI and enhances } \\
\text { Smad2/3 activation. NRP2 induces a TGF } \beta 1 \text { - } \\
\text { dependant Epithelial Mesenchymal Transition } \\
\text { in colorectal cancer cells. }\end{array}$ & $\begin{array}{l}\text { Grandclement } \\
\text { et al., } 2010 \\
{[143]}\end{array}$ \\
\hline
\end{tabular}




\subsubsection{Integrins}

Integrins have important roles in cell attachment, survival, migration, invasion and angiogenesis, which are all critical for carcinogenesis. Many integrins have been implicated in cancer progression. Indeed, Fukasawa and colleagues show that NRP1 interacts with integrin- $\beta 1$ in pancreatic ductal adenocarcinoma and in this way promotes tumor cell growth, survival and invasion [134]. NRP1 was suggested to interact with $\alpha 5 \beta 1$ integrin to regulate angiogenesis in endothelial cells [135]. In lung cancer cells, anti-tumor effect of Sema3F is associated with loss of activated $\alpha 5 \beta 3$ integrin [121]. However, some integrins can support opposite activities. For example, in breast tumor cells, Sema3A treatment reduces cell migration in increasing $\alpha 2 \beta 1$ integrin level [127]. In endothelial cells, $\beta 3$ integrin inhibits VEGF-mediated angiogenesis by sequestering NRP1 and preventing it from interacting with VEGFR2 [136].

\subsection{3. c-met}

Because heparin growth factors FGF and HGF have been recently identified as NRPs ligands, they are believed to contribute to NRP-mediated angiogenesis too. Indeed, NRP1 potentiates HGF and FGF2 induced proliferation, survival, invasion in human umbilical vein endothelial cells (HUVEC), glioma cells, pancreatic cancer cells $[23,137,138]$. It appears that NRPs can be a receptor for HGF but can also enhance c-met phosphorylation by activating the c-met receptor itself. Indeed, co-immunoprecipitation studies confirm that NRPs interact directly with c-met receptor [138] (Table 3). Sulpice et al. confirmed in 2008 that both NRPs participate to VEGF and HGF linked-angiogenic activity in endothelial cells through enhancing autocrine hepatocyte growth factor (HGF)/scatter factor (SF)/c-Met signaling [24,137]. NRPs generate activation of several signaling pathways through c-met interaction, including p38-mitogen-activated protein kinase (p38-MAPK), extracellular signal-regulated kinase (ERK), src, phosphatidylinositol 3-kinase (PI3K) [24,137,138] (Figure 4).

\subsubsection{TGFRs}

More recently, a study suggested that NRP1 is a receptor for both active TGF $\beta 1$ and TGF $\beta 1$-LAP. In addition, NRP1-TGF $\beta 1$ interactions on T cells resulted in enhanced T regulator activity [139]. Then other reports confirmed that NRP1 promotes TGF $\beta 1$ signaling pathway. Indeed, in a recent study, Glinka et al. show that NRP1 associates with TGFRI and TGFRII to enhance TGF $\beta 1$ signaling in cancer cells [140] (Table 3). Moreover, NRP1 was shown to confer a myofibroblast phenotype by enhancing PDGF/TGF $\beta 1$ pathways in hepatic human cells [141] and in stromal fibroblasts [142]. Because NRPs are not tyrosine-kinase receptors, NRP1 was thought to cooperate with TGFRs to transduce the signal [142]. A similar role was attributed to NRP2. Indeed, we noticed that NRP2 expression enhances TGF $\beta 1$ signaling leading to constitutive Smad2/3 phosphorylation in colorectal cancer cells [143]. Biacore analysis revealed that NRP2, like NRP1, is a receptor for active TGF $\beta 1$ [143]. Moreover, NRP2 confered a fibroblastic-like shape to cancer cells, suggesting an involvement of neuropilin-2 in epithelial mesenchymal transition (EMT) [143] (Table 3). EMT is indeed characterized by a breakdown of cell junctions and the loss of epithelial characteristics and cell polarity, contributing to carcinoma progression. Besides the gain of mesenchymal markers, EMT endows cancer cells for 
migration, invasiveness and subsequent metastasis formation [144]. Indeed, the presence of neuropilin-2 in colorectal carcinoma cell lines is correlated with loss of epithelial markers such as cytokeratin-20 and E-cadherin and with acquisition of mesenchymal molecules such as vimentin [143].

In view of its implication in multiple processes such as angiogenesis, lymphangiogenesis, EMT, and metastasis, NRP2 fulfills all the criteria of a therapeutic target to disrupt multiple oncogenic functions in solid tumors.

\section{Neuropilins: A Surrogate Marker for Cancer Progression}

Because NRP2 is implicated in multiple processes including angiogenesis, lymphangiogenesis and metastasis, it became rapidly apparent that NRP2 detection constitutes a novel diagnostic and prognostic tool in a great majority of tumors.

NRP2 expression is correlated twith increased vascularity and poor prognosis in osteosarcomas [39] and non small cell lung carcinoma (NSCLC) [41]. Nrp2 was also detected in salivary adenoid cystic carcinomas (SACCs), and its expression level significantly correlated with microvessel density, tumor size, clinical stage, vascular invasion, and metastasis of SACCs [54]. In breast cancers, NRP2 expression is significantly correlated with lymph node metastasis, VEGF-C expression and cytoplasmic CXCR4 expression [50]. NRP2 expression is significantly upregulated in early and advanced stages of neuroblastomas [44]. Moreover, NRP2 is expressed by a vast majority of endocrines pancreatic tumors, suggesting that NRP2 can be used as a diagnostic marker for these tumors [47]. NRP2 was shown to be also a biomarker of potential clinical significance associated with bladder cancer progression [55].

\section{Neuropilins Targeting}

Several tools have been developed to neutralize NRPs receptors, targeting NRPs genes like RNA interference or receptors using specific monoclonal antibodies or small peptides (Figure 5).

\subsection{RNA Interference}

Use of siRNA targeting NRP1 significantly reduces tumor growth, angiogenesis, metastasis formation in various human cancer models, such as hepatocellular carcinoma [145,146], acute myeloid leukemia [67], lung cancer [147]. Also reduction of NRP2 expression by shRNA in colorectal cancer cells induces smaller tumors, decreased number of metastases and enhanced apoptosis in comparison with control shRNA in a murine xenograft model [45]. In addition, intraperitoneally treatment of tumor bearing mice with liposomes containing NRP2 siRNA reduces tumor growth and metastasis [45]. 
Figure 5. Biotechnological tools developped to target NRPs. Preclinical studies demonstrated the potential interest of several strategies to inhibit oncogenic functions induced by NRPs including: small interfering RNA, peptides, soluble NRPs antagonists, monoclonal antibodies (RISC: «RNA-Induced Silencing Complex»).

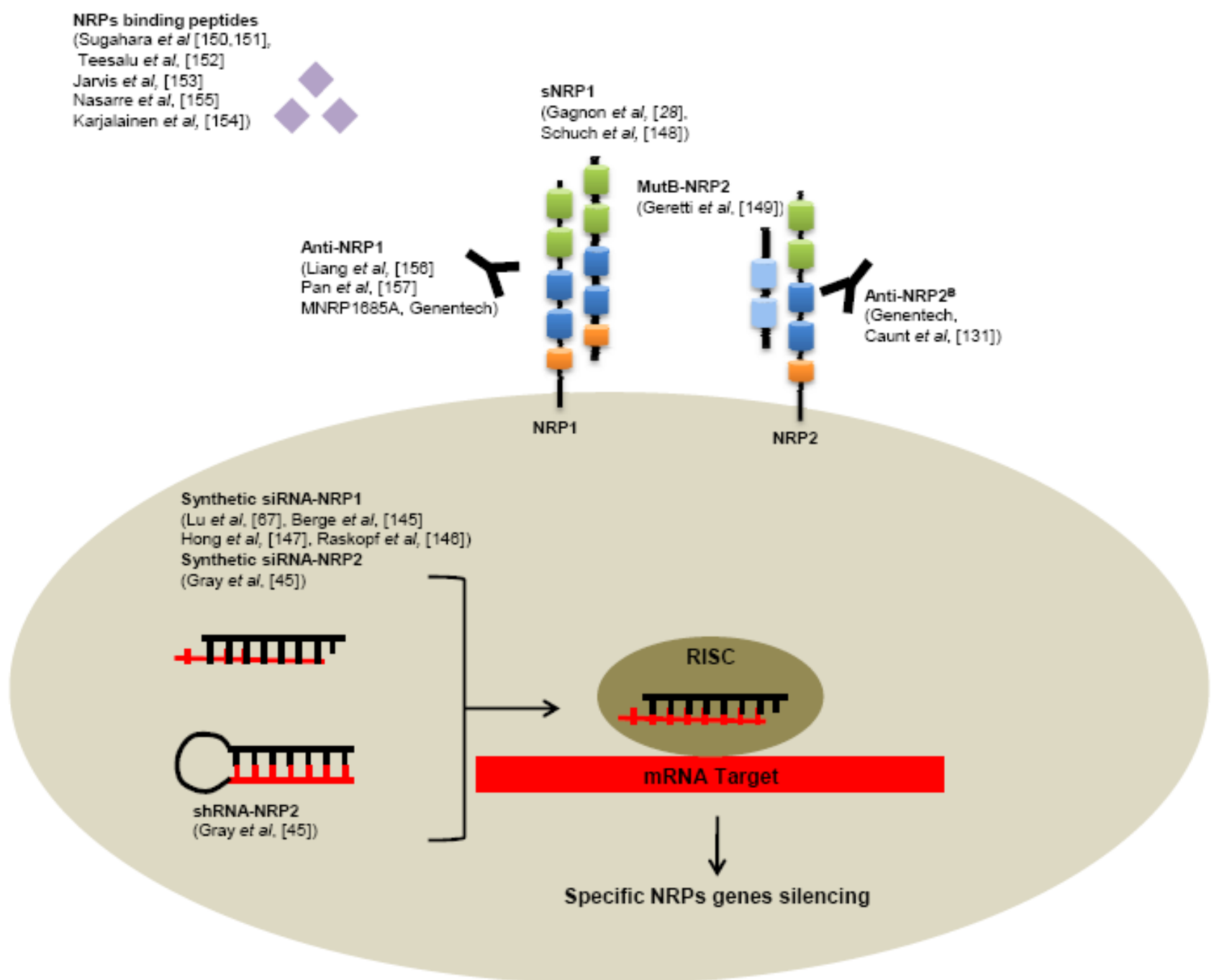

\subsection{Small Molecules}

As seen previously, alternative splicing generates naturally occurring soluble forms sNRP1 and SNRP2. These soluble sNRP are first described as inhibitory molecules, functioning as natural ligand trap, inhibiting their interaction with membrane receptors. Soluble neuropilins lack the transmembrane segment and intracellular domain. Gagnon et al. reported that overexpression of sNRP1 in Dunning rat prostate carcinoma cell lines AT2.1 and AT3.1 generates tumors with large and hemorrhagic center, with decreased proliferation and increased apoptosis in rats [28]. Moreover, sNRP1 inhibits the binding of VEGF 165 to full-length NRP1 [28].

Schuch et al. confirmed these findings in a murine sarcoma model using NMuMG/VEGF and NMuMG/sNRP-1 cells that have been engineered to produce high levels of recombinant VEGF and SNRP1 [148]. VEGF treatment resulted in tumor growth and vascularization, whereas treatment with 
soluble NRP-1 (sNRP-1) inhibited tumor angiogenesis and growth. Moreover, in a systemic leukemia model, survival of mice injected with adenovirus (Ad) encoding for Fc-sNRP-1 (sNRP-1 dimer) was significantly prolonged as compared with control mice [148].

Since naturally occurring soluble forms of neuropilins are described to inhibit tumor progression, researchers tend nowadays to develop soluble peptides preventing VEGF-binding on neuropilins. For this purpose, Geretti et al. described very recently a mutant of the B-domain of NRP2 (MutB-NRP2) with 8-fold increased affinity for VEGF compared to wild-type B domain of NRP2 [149]. This MutB-NRP2 significantly inhibits tumor growth in a xenograft model using melanoma cells, alone and in combination with bevacizumab [149].

Furthermore, screening of phage libraries expressing random peptides binding to various cancer cells has allowed the identification of amino acid sequences especially binding NRPs. Indeed, Sugahara and collaborators reported two tissue-penetrating peptides binding human integrins and NRP1 capable of penetrating into tumor tissue and cells [150,151]. Conjugation of these peptides to anti-tumor drugs or imaging agents might enhance tumor imaging and the activity of anti-tumor therapies [150-152]. Since then, another peptide targeting NRP1 has been described in various model of cancers cell in vitro [153-155].

\subsection{Monoclonal Antibodies}

Genentech has very recently developed monoclonal antibodies targeting NRP1. In particularly, high-affinity monoclonal antibodies targeting either CUB domains (anti-NRP1 ${ }^{\mathrm{A}}$ ) or coagulation factors V/VIII domains (anti-NRP1 ${ }^{\mathrm{B}}$ ) of NRP1 have been first generated. [156] These anti-NRP1 antibodies induce reduction of VEGF-induced migration of HUVEC cells and inhibit tumor formation in animal models [156]. Later, anti-NRP1 monoclonal antibodies were shown to block VEGF-binding to NRP1 and to have an additive effect with anti-VEGF therapies to reduce tumor growth [157].

One of them, a full human antibody targeting NRP1, MNRP1685A is actually in phase-1 of development alone or in combination with bevacizumab with or without paclitaxel for treatment of advanced solid tumors [158].

Monoclonal antibodies targeting the b1/b2 domains of NRP2 have been recently developed. By blocking binding of VEGF and VEGFC to NRP2, these anti-NRP2 ${ }^{\mathrm{B}}$ monoclonal antibodies decrease the number of tumor-associated lymphatic vessels and metastasis in sentinel lymph node and in distant organs in mice xenograft experiments [131].

\subsection{Semaphorins}

NRPs role in tumorigenesis is more complex than initially thought and appears to depend on the nature of the ligand. In the context of cancer, it appears that semaphorins and VEGF are competing for NRPs binding, although they bind different NRPs sub-units. While semaphorins are responsible for inhibition of tumor growth, proliferation and even induction of apoptosis in cancer cells, VEGF tends to oppositely enhance angiogenesis and tumor growth. As described above, some semaphorins such as Sema3B and Sema3F are considered as TSG and are very often downregulated in cancer cells $[102,104,120]$. Overexpression of Sema3 genes may represent a promising new type of therapy for preventing tumor angiogenesis, growth, and metastasis. Moreover, other semaphorins such as 
Sema3E or Sema4D function as pro-angiogenic and pro-oncogenic molecules $[89,126,159,160]$. Neutralization of these molecules or their relative receptors thus may represent a new therapeutic strategy for cancer treatment. In particular, one monoclonal antibody VX15/2503 binding to the sema4D is currently in phase-1 of development for the treatment of advanced solid tumors [161]. Therapeutic use of semaphorin pathway seems to represent one of the major therapeutic strategies considered, capable of antagonizing VEGF-mediated angiogenesis and tumor progression [88].

\section{Conclusions}

NRPs are multifunctional non-tyrosine kinase receptors for class-3 semaphorins and VEGF family members implicated in both physiological development and pathological situations. NRPs are expressed in endothelial cells and in many types of cancer cells. Through their direct interactions with plexins or growth factor receptors, NRPs have rapidly emerged as key regulators of angiogenesis, lymphangiogenesis, EMT and tumor progression. In many cancers, expression of one or both has been correlated with tumor progression and/or poor prognosis. As a consequence, several strategies have been used in pre-clinical studies to inhibit NRPs function, such as knockdown strategies with siRNAs, small peptide inhibitors, and blocking antibodies. However, the molecular mechanisms by which NRPs modulate cancer progression are still poorly understood. Understanding the interactions between VEGF, VEGFRs, semaphorins and NRPs should provide additional data for the rational development of novel anti-tumor strategies.

\section{Acknowledgments}

C.G. has received a fellowship from the "ANRT: Agence Nationale pour la Recherche Technologique"; This work has been supported by the "Ligue contre le cancer, comité du Doubs", and by the University Hospital of Besançon.

\section{References}

1. Takagi, S.; Tsuji, T.; Amagai, T.; Takamatsu, T.; Fujisawa, H. Specific cell surface labels in the visual centers of Xenopus laevis tadpole identified using monoclonal antibodies. Dev. Biol. 1987, $122,90-100$.

2. Takagi, S.; Kasuya, Y.; Shimizu, M.; Matsuura, T.; Tsuboi, M.; Kawakami, A.H.F. Expression of a cell adhesion molecule, neuropilin, in the developing chick nervous system. Dev. Biol. 1995, 170, 207-222.

3. Yamagata, M.; Herman, J.P.; Sanes, J.R. Lamina-specific expression of adhesion molecules in developing chick optic tectum. J. Neurosci. 1995, 15, 4556-4571.

4. Kawakami, A.; Kitsukawa, T.; Takagi, S.H.F. Developmentally regulated expression of a cell surface protein, neuropilin, in the mouse nervous system. J. Neurobiol. 1996, 29, 1-17.

5. Kolodkin, A.; Levengood, D.; Rowe, E.; Tai, Yu-Tzu.; Giger, R.; Ginty, D. Neuropilin is a Semaphorin III receptor. Cell 1997, 90, 753-762.

6. He, Z.; Tessier-Lavigne, M. Neuropilin is a receptor for the axonal chemorepellent Semaphorin III. Cell 1997, 90, 739-751. 
7. Chen, H.; Chedotal, A.; He, Z.; Goodman, C.S.; Tessier-Lavigne, M. Neuropilin-2, a novel member of the neuropilin family, is a high affinity receptor for the semaphorins Sema E and Sema IV but not Sema III. Neuron 1997, 19, 547-559.

8. Giger, R.J.; Urquhart, E.R.; Gillespie, S.K.; Levengood, D.V.; Ginty, D.D.; Kolodkin, A.L. Neuropilin-2 is a receptor for semaphorin IV: Insight into the structural basis of receptor function and specificity. Neuron 1998 21, 1079-1092.

9. Giger, R.J.; Cloutier, J.F.; Sahay, A.; Prinjha, R.K.; Levengood, D.V.; Moore, S.E.; Pickering, S.; Simmons, D.; Rastan, S.; Walsh, F.S.; et al. Neuropilin-2 is required in vivo for selective axon guidance responses to secreted semaphorins. Neuron 2000, 25, 29-41.

10. Kitsukawa, T.; Shimizu, M.; Sanbo, M.; Hirata, T.; Taniguchi, M.; Bekku, Y.; Yagi, T.; Fujisawa, H. Neuropilin-semaphorin III/D-mediated chemorepulsive signals play a crucial role in peripheral nerve projection in mice. Neuron 1997, 19, 995-1005.

11. Chen, H.; Bagri, A.; Zupicich, J.A. Neuropilin-2 regulates the development of selective cranial and sensory nerves and hippocampal mossy fiber projections. Neuron 2000, 25, 43-56.

12. Kitsukawa, T.; Shimono, A.; Kawakami, A.; Kondoh, H.; Fujisawa, H. Overexpression of a membrane protein, neuropilin, in chimeric mice causes anomalies in the cardiovascular system, nervous system and limbs. Development 1995, 121, 4309-4318.

13. Kawasaki, T.; Kitsukawa, T.; Bekku, Y.; Matsuda, Y.; Sanbo, M.; Yagi, T.; Fujisawa, H. A requirement for neuropilin-1 in embryonic vessel formation. Development 1999, 126, 4895-4902.

14. Takashima, S.; Kitakaze, M.; Asakura, M.; Asanuma, H.; Sanada, S.; Tashiro, F.; Niwa, H.; Miyazaki Ji, J.; Hirota, S.; Kitamura, Y.; et al. Targeting of both mouse neuropilin-1 and neuropilin-2 genes severely impairs developmental yolk sac and embryonic angiogenesis. Proc. Natl. Acad. Sci. USA 2002, 99, 3657-3662.

15. Yuan, L.; Moyon, D.; Pardanaud, L.; Breant, C.; Karkkainen, M.J.; Alitalo, K.; Eichmann, A. Abnormal lymphatic vessel development in neuropilin 2 mutant mice. Development 2002, 129, 4797-4806.

16. Mäkinen, T.; Olofsson, B.; Karpanen, T.; Hellman, U.; Soker, S.; Klagsbrun, M.; Eriksson, U.; Alitalo, K. Differential binding of vascular endothelial growth factor B splice and proteolytic isoforms to neuropilin-1. J. Biol. Chem. 1999, 274, 21217-21222.

17. Migdal, M.; Huppertz, B.; Tessler, S.; Comforti, A.; Shibuya, M.; Reich, R.; Baumann, H.; Neufeld, G. Neuropilin-1 is a placenta growth factor-2 receptor. J. Biol. Chem. 1998, 273, 22272-22278.

18. Gluzman-Poltorak, Z.; Cohen, T.; Herzog, Y.; Neufeld, G. Neuropilin-2 and neuropilin-1 are receptors for the 165-amino acid form of vascular endothelial growth factor (VEGF) and of placenta growth factor-2, but only neuropilin-2 functions as a receptor for the 145-amino acid form of VEGF. J. Biol. Chem. 2000, 275, 18040-18045.

19. Fuh, G.; Garcia, K.C.; de Vos, A.M. The interaction of neuropilin-1 with vascular endothelial growth factor and its receptor flt-1. J. Biol. Chem. 2000, 275, 26690-26695.

20. Kärpänen, T.; Heckman, C.A.; Keskitalo, S.; Jeltsch, M.; Ollila, H.; Neufeld, G.; Tamagnone, L.; Alitalo, K. Functional interaction of VEGF-C and VEGF-D with neuropilin receptors. FASEB J. 2006, 20, 1462-1472. 
21. Soker, S.; Takashima, S.; Miao, H.Q.; Neufeld, G.; Klagsbrun, M. Neuropilin-1 is expressed by endothelial and tumor cells as an isoform-specific receptor for vascular endothelial growth factor. Cell 1998, 92, 735-745.

22. Karkkainen, M.J.; Saaristo, A.; Jussila, L.; Karila, K.A.; Lawrence, E.C.; Pajusola, K.; Bueler, H.; Eichmann, A.; Kauppinen, R.; Kettunen, M.I.; et al. A model for gene therapy of human hereditary lymphedema. Proc. Natl. Acad. Sci. USA 2001, 98, 12677-12682.

23. West, D.C.; Rees, C.G.; Duchesne, L.; Patey, S.J.; Terry, C.J.; Turnbull, J.E.; Delehedde, M.; Heegaard, C.W.; Allain, F.; Vanpouille, C.; et al. Interactions of multiple heparin binding growth factors with neuropilin-1 and potentiation of the activity of fibroblast growth factor-2. J. Biol. Chem. 2005, 280, 13457-13464.

24. Sulpice, E.; Plouët, J.; Bergé, M.; Allanic, D.; Tobelem, G.; Merkulova-Rainon, T. Neuropilin-1 and neuropilin-2 act as coreceptors, potentiating proangiogenic activity. Blood 2008, 111, 2036-2045.

25. Rossignol, M.; Gagnon, M.L.; Klagsbrun, M. Genomic organization of human neuropilin-1 and neuropilin-2 genes: Identification and distribution of splice variants and soluble isoforms. Genomics 2000, 70, 211-222.

26. Takagi, S.; Hirata, T.; Agata, K.; Mochii, M.; Eguchi, G.; Fujisawa, H. The A5 antigen, a candidate for the neuronal recognition molecule, has homologies to complement components and coagulation factors. Neuron 1991, 7, 295-307.

27. Cackowski, F.C.; Xu, L.; Hu, B.; Cheng, S.Y. Identification of two novel alternatively spliced Neuropilin-1 isoforms. Genomics 2004, 84, 82-94.

28. Gagnon, M.L.; Bielenberg, D.R.; Gechtman, Z.; Miao, H.Q.; Takashima, S.; Soker, S.; Klagsbrun, M. Identification of a natural soluble neuropilin-1 that binds vascular endothelial growth factor: In vivo expression and antitumor activity. Proc. Natl. Acad. Sci. USA 2000, 97, 2573-2578.

29. Fujisawa, H.; Takagi, S.; Hirata, T. Growth-associated expression of a membrane protein, neuropilin, in Xenopus optic nerve fibers. Dev. Neurosci. 1995, 17, 343-349.

30. Tordjman, R.; Lepelletier, Y.; Lemarchandel, V.; Cambot, M.; Gaulard, P.; Hermine, O.; Roméo, P.H. A neuronal receptor, neuropilin-1, is essential for the initiation of the primary immune response. Nat. Immunol. 2002, 3, 477-482.

31. Bruder, D.; Probst-Kepper, M.; Westendorf, A.M.; Geffers, R.; Beissert, S.; Loser, K.; von Boehmer, H.; Buer, J.; Hansen, W. Neuropilin-1: A surface marker of regulatory T cells. Eur. J. Immunol. 2004, 34, 623-630.

32. Sarris, M.; Andersen, K.G.; Randow, F.; Mayr, L.; Betz, A.G. Neuropilin-1 expression on regulatory $\mathrm{T}$ cells enhances their interactions with dendritic cells during antigen recognition. Immunity 2008, 28, 402-413.

33. Milpied, P.; Renand, A.; Bruneau, J.; Mendes-da-Cruz, D.A.; Jacquelin, S.; Asnafi, V.; Rubio, M.T.; MacIntyre, E.; Lepelletier, Y.; Hermine, O. Neuropilin-1 is not a marker of human Foxp3+ Treg. Eur. J. Immunol. 2009, 39, 1466-1471.

34. Curreli, S.; Arany, Z.; Gerardy-Schahn, R.; Mann, D.; Stamatos, N.M. Polysialylated neuropilin-2 is expressed on the surface of human dendritic cells and modulates dendritic cell-T lymphocyte interactions. J. Biol. Chem. 2007, 282, 30346-30356. 
35. Rey-Gallardo, A.; Delgado-Martín, C.; Gerardy-Schahn, R.; Rodríguez-Fernández, J.L.; Vega, M.A. Polysialic acid is required for Neuropilin-2a/b-mediated control of CCL21-driven chemotaxis of mature dendritic cells, and for their migration in vivo. Glycobiology 2011, doi: 10.1093/glycob/cwq216.

36. Rey-Gallardo, A.; Escribano, C.; Delgado-Martín, C.; Rodriguez-Fernández, J.L.; Gerardy-Schahn, R.; Rutishauser, U.; Corbi, A.L.; Vega, M.A. Polysialylated neuropilin-2 enhances human dendritic cell migration through the basic C-terminal region of CCL21. Glycobiology 2010, 20, 1139-1146.

37. Bielenberg, D.R.; Pettaway, C.A.; Takashima, S.; Klagsburn, M. Neuropilins in neoplasms: Expression, regulation, and function. Exp. Cell Res. 2006, 312, 584-593.

38. Pellet-Many, C.; Frankel, P.; Jia, H.; Zachary, I. Neuropilins: Structure, function and role in disease. Biochem. J. 2008, 411, 211-226.

39. Handa, A.; Tokunaga, T.; Tsuchida, T.; Lee, Y.H.; Kijima, H.; Yamazaki, H.; Ueyama, Y.; Fukuda, H.; Nakamura, M. Neuropilin-2 expression affects the increased vascularization and is a prognostic factor in osteosarcoma. Int. J. Oncol. 2000, 17, 291-295.

40. Lacal, P.M.; Failla, C.M.; Pagani, E.; Odorisio, T.; Schietroma, C.; Falcinelli, S.; Zambruno, G.; D'Atri, S. Human melanoma cells secrete and respond to placenta growth factor and vascular endothelial growth factor. J. Invest. Dermatol. 2000, 115, 1000-1007.

41. Kawakami, T.; Tokunaga, T.; Hatanaka, H.; Kijima, H.; Yamazaki, H.; Abe, Y.; Osamura, Y.; Inoue, H.; Ueyama, Y.; Nakamura, M. Neuropilin 1 and neuropilin 2 co-expression is significantly correlated with increased vascularity and poor prognosis in nonsmall cell lung carcinoma. Cancer 2002, 95, 2196-2201.

42. Tomizawa, Y.; Sekido, Y.; Kondo, M.; Gao, B.; Yokota, J.; Roche, J.; Drabkin, H.; Lerman, M.I.; Gazdar, A.F.; Minna, J.D. Inhibition of lung cancer cell growth and induction of apoptosis after reexpression of 3p21.3 candidate tumor suppressor gene SEMA3B. Proc. Natl. Acad. Sci. USA 2001, 98, 13954-13959.

43. Rieger, J.; Wick, W.; Weller, M. Human malignant glioma cells express semaphorins and their receptors, neuropilins and plexins. Glia 2003, 42, 379-389.

44. Fakhari, M.; Pullirsch, D.; Abraham, D.; Paya, K.; Hofbauer, R.; Holzfeind, P.; Hofmann, M.; Aharinejad, S. Selective upregulation of vascular endothelial growth factor receptors neuropilin-1 and -2 in human neuroblastoma. Cancer 2002, 94, 258-263.

45. Gray, M.J.; Van Buren, G.; Dallas, N.A.; Xia, L.; Wang, X.; Yang, A.D.; Somcio, R.J.; Lin, Y.G.; Lim, S.; Fan, F.; et al. Therapeutic targeting of neuropilin-2 on colorectal carcinoma cells implanted in the murine liver. J. Nat. Cancer Inst. 2008, 100 109-120.

46. Dallas, N.A.; Gray, M.J.; Xia, L.; Fan, F.; van Buren, G., 2nd.; Gaur, P.; Samuel, S.; Lim, S.J.; Arumugam, T.; Ramachandran, V.; Wang, H.; Ellis, L.M. Neuropilin-2-mediated tumor growth and angiogenesis in pancreatic adenocarcinoma. Clin. Cancer Res. 2008, 14, 8052-8060.

47. Cohen, T.; Herzog, Y.; Brodzky, A.; Greenson, J.K.; Eldar, S.; Gluzman-Poltorak, Z.; Neufeld, G.; Resnick, M.B. Neuropilin-2 is a novel marker expressed in pancreatic islet cells and endocrine pancreatic tumours. J. Pathol. 2002, 198, 77-82.

48. Fukahi, K.; Fukasawa, M.; Neufeld, G.; Itakura, J.; Korc, M. Aberrant expression of neuropilin-1 and -2 in human pancreatic cancer cells. Clin. Cancer Res. 2004, 10, 581-590. 
49. Li, M.; Yang, H.; Chai, H.; Fisher, W.E.; Wang, X.; Brunicardi, F.C.; Yao, Q.; Chen, C. Pancreatic carcinoma cells express neuropilins and vascular endothelial growth factor, but not vascular endothelial growth factor receptors. Cancer 2004, 101, 2341-2350.

50. Yasuoka, H.; Kodama, R.; Tsujimoto, M.; Yoshidome, K.; Akamatsu, H.; Nakahara, M.; Inagaki, M.; Sanke, T.; Nakamura, Y. Neuropilin-2 expression in breast cancer: Correlation with lymph node metastasis, poor prognosis, and regulation of CXCR4 expression. BMC Cancer 2009, 7, 220.

51. Vales, A.; Kondo, R.; Aichberger, K.J.; Mayerhofer, M.; Kainz, B.; Sperr, W.R.; Sillaber, C.; Jäger, U.; Valent, P. Myeloid leukemias express a broad spectrum of VEGF receptors including neuropilin-1 (NRP-1) and NRP-2. Leuk. Lymphoma 2007, 48, 1997-2007.

52. Cai, Y.; Wang, R.; Zhao, Y.F.; Jia, J.; Sun, Z.J.; Chen, X.M. Expression of Neuropilin-2 in salivary adenoid cystic carcinoma: Its implication in tumor progression and angiogenesis. Pathol. Res. Pract. 2010, 206, 793-799.

53. Calicchio, M.L.; Collins, T.; Kozakewich, H.P. Identification of signaling systems in proliferating and involuting phase infantile hemangiomas by genome-wide transcriptional profiling. Am. J. Pathol. 2009, 174, 1638-1649.

54. Osada, R.; Horiuchi, A.; Kikuchi, N.; Ohira, S.; Ota, M.; Katsuyama, Y.; Konishi, I. Expression of semaphorins, vascular endothelial growth factor, and their common receptor neuropilins and alleic loss of semaphorin locus in epithelial ovarian neoplasms: Increased ratio of vascular endothelial growth factor to semaphorin is a poor prognostic factor in ovarian carcinomas. Hum. Pathol. 2006, 37, 1414-1425.

55. Sanchez-Carbayo, M.; Socci, N.D.; Lozano, J.J.; Li, W.; Charytonowicz, E.; Belbin, T.J.; Prystowsky, M.B.; Ortiz, A.R.; Childs, G.; Cordon-Cardo, C. Gene discovery in bladder cancer progression using cDNA microarrays. Am. J. Pathol. 2003, 163, 505-516.

56. Ding, H.; Wu, X.; Roncari, L.; Lau, N.; Shannon, P.; Nagy, A.; Guha, A. Expression and regulation of neuropilin-1 in human astrocytomas. Int. J. Cancer 2000, 88, 584-592.

57. Broholm, H.; Laursen, H. Vascular endothelial growth factor (VEGF) receptor neuropilin-1's distribution in astrocytic tumors. APMIS 2004, 112, 257-263.

58. Onofri, C.; Theodoropoulou, M.; Losa, M.; Uhl, E.; Lange, M.; Arzt, E.; Stalla, G.K.; Renner, U. Localization of vascular endothelial growth factor (VEGF) receptors in normal and adenomatous pituitaries: detection of a non-endothelial function of VEGF in pituitary tumours. J. Endocrinol. 2006, 191, 249-261.

59. Parikh, A.A.; Liu, W.B.; Fan, F. Expression and regulation of the novel vascular endothelial growth factor receptor neuropilin-1 by epidermal growth factor in human pancreatic carcinoma. Cancer 2003, 98, 720-729.

60. Feurino, L.W.; Zhang, Y.; Bharadwaj, U.; Zhang, R.; Li, F.; Fisher, W.E.; Brunicardi, F.C.; Chen, C.; Yao, Q.; Min, L. IL-6 stimulates Th2 type cytokine secretion and upregulates VEGF and NRP-1 expression in pancreatic cancer cells. Cancer Biol. Ther. 2007, 6, 1096-1100.

61. Akagi, M.; Kawaguchi, M.; Liu, W.; McCarty, M.F.; Takeda, A.; Fan, F.; Stoeltzing, O.; Parikh, A.A.; Jung, Y.D.; Bucana, C.D.; et al. Induction of neuropilin-1 and vascular endothelial growth factor by epidermal growth factor in human gastric cancer cells. Br. J. Cancer 2003, 88, 796-802. 
62. Hansel, D.E.; Wilentz, R.E.; Yeo, C.J.; Schulick, R.D.; Montgomery, E.; Maitra, A. Expression of neuropilin-1 in high-grade dysplasia, invasive cancer, and metastases of the human gastrointestinal tract. Am. J. Surg. Pathol. 2004, 28, 347-356.

63. Parikh, A.A.; Fan, F.; Liu, W.B. Neuropilin-1 in human colon cancer: Expression, regulation, and role in induction of angiogenesis. Am. J. Path. 2004, 164, 2139-2151.

64. Ochiumi, T.; Kitadai, Y.; Tanaka, S.; Akagi, M.; Yoshihara, M.; Chayama, K. Neuropilin-1 is involved in regulation of apoptosis and migration of human colon cancer. Int. J. Oncol. 2006, 29, 105-116.

65. Kreuter, M.; Woelke, K.; Bieker, R.; Schliemann, C.; Steins, M.; Buechner, T.; Berdel, W.E.; Mesters, R.M. Correlation of neuropilin-1 overexpression to survival in acute myeloid leukemia. Leukemia 2006, 20, 1950-1954.

66. Kreuter, M.; Steins, M.; Woelke, K.; Buechner, T.; Berdel, W.E.; Mesters, R.M. Downregulation of neuropilin-1 in patients with acute myeloid leukemia treated with thalidomide. Eur. J. Haematol. 2007, 79, 392-397.

67. Lu, L.; Zhang, L.; Xiao, Z.; Lu, S.; Yang, R.; Han, Z.C. Neuropilin-1 in acute myeloid leukemia: expression and role in proliferation and migration of leukemia cells. Leuk. Lymphoma 2008, 49, 331-338.

68. Nowakowski, G.S.; Mukhopadhyay, D.; Wu, X.; Kay, N.E. Neuropilin-1 is expressed by chronic lymphocytic leukemia B cells. Leuk. Res. 2008, 32, 1634-1636.

69. Stephenson, J.M.; Banerjee, S.; Saxena, N.K.; Cherian, R.; Banerjee, S.K. Neuropilin-1 is differentially expressed in myoepithelial cells and vascular smooth muscle cells in preneoplastic and neoplastic human breast: A possible marker for the progression of breast cancer. Int. J. Cancer 2002, 101, 409-414.

70. Ghosh, S.; Sullivan, C.A.; Zerkowski, M.P.; Molinaro, A.M.; Rimm, D.L.; Camp, R.L.; Chung, G.G. High levels of vascular endothelial growth factor and its receptors (VEGFR-1, VEGFR-2, neuropilin-1) are associated with worse outcome in breast cancer. Hum. Pathol. 2008, 39, 1835-1843.

71. Lantuéjoul, S.; Constantin, B.; Drabkin, H.; Brambilla, C.; Roche, J.; Brambilla, E. Expression of VEGF, semaphorin SEMA3F, and their common receptors neuropilins NP1 and NP2 in preinvasive bronchial lesions, lung tumours, and cell lines. J. Pathol. 2003, 200, 336-347.

72. Straume, O.; Akslen, L.A. Increased expression of VEGF-receptors (FLT-1, KDR, NRP-1) and thrombospondin-1 is associated with glomeruloid microvascular proliferation, an aggressive angiogenic phenotype, in malignant melanoma. Angiogenesis 2003, 6, 295-301.

73. Latil, A.; Bièche, I.; Pesche, S.; Valéri, A.; Fournier, G.; Cussenot, O.; Lidereau, R. VEGF overexpression in clinically localized prostate tumors and neuropilin-1 overexpression in metastatic forms. Int. J. Cancer 2000, 89, 167-171.

74. Vanveldhuizen, P.J.; Zulfiqar, M.; Banerjee, S.; Cherian, R.; Saxena, N.K.; Rabe, A.; Thrasher, J.B.; Banerjee, S.K. Differential expression of neuropilin-1 in malignant and benign prostatic stromal tissue. Oncol. Rep. 2003, 10, 1067-1071.

75. Zhang, S.; Kong, W. Expression of neuropilin-1 in human laryngeal carcinoma and cell lines. Lin Chuang Er Bi Yan Hou Ke Za Zhi 2006, 20, 634-635. 
76. Hall, G.H.; Turnbull, L.W.; Bedford, K.; Richmond, I.; Helboe, L.; Atkin, S.L. Neuropilin-1 and VEGF correlate with somatostatin expression and microvessel density in ovarian tumours. Int. J. Oncol. 2005, 27, 1283-1288.

77. Baba, T.; Kariya, M.; Higuchi, T.; Mandai, M.; Matsumura, N.; Kondoh, E.; Miyanishi, M.; Fukuhara, K.; Takakura, K.; Fujii, S. Neuropilin-1 promotes unlimited growth of ovarian cancer by evading contact inhibition. Gynecol. Oncol. 2007, 105, 703-711.

78. Ottino, P.; Finley, J.; Rojo, E.; Ottlecz, A.; Lambrou, G.N.; Bazan, H.E.; Bazan, N.G. Hypoxia activates matrix metalloproteinase expression and the VEGF system in monkey choroid-retinal endothelial cells: Involvement of cytosolic phospholipase A2 activity. Mol. Vis. 2004, 10, 341-350.

79. Brusselmans, K.; Bono, F.; Collen, D.; Herbert, J.M.; Carmeliet, P.; Dewerchin, M. A novel role for vascular endothelial growth factor as an autocrine survival factor for embryonic stem cells during hypoxia. J. Biol. Chem. 2005, 280, 3493-3499.

80. Jögi, A.; Vallon-Christersson, J.; Holmquist, L.; Axelson, H.; Borg, A.; Påhlman, S. Human neuroblastoma cells exposed to hypoxia: Induction of genes associated with growth, survival, and aggressive behavior. Exp. Cell Res. 2004, 295, 469-487.

81. Zhang, Z.G.; Tsang, W.; Zhang, L.; Powers, C.; Chopp, M. Up-regulation of neuropilin-1 in neovasculature after focal cerebral ischemia in the adult rat. J. Cereb. Blood Flow Metab. 2001, 21, 541-549.

82. Beck, H.; Acker, T.; Püschel, A.W.; Fujisawa, H.; Carmeliet, P.; Plate, K.H. Cell type-specific expression of neuropilins in an MCA-occlusion model in mice suggests a potential role in post-ischemic brain remodeling. J. Neuropathol. Exp. Neurol. 2002, 61, 339-350.

83. Li, M.; Zhang, Y.; Feurino, L.W.; Wang, H.; Fisher, W.E.; Brunicardi, F.C.; Chen, C.; Yao, Q. Interleukin-8 increases vascular endothelial growth factor and neuropilin expression and stimulates ERK activation in human pancreatic cancer. Cancer Sci. 2008, 99, 733-737.

84. Giraudo, E.; Primo, L.; Audero, E.; Gerber, H.P.; Koolwijk, P.; Soker, S.; Klagsbrun, M.; Ferrara, N.; Bussolino, F. Tumor necrosis factor-alpha regulates expression of vascular endothelial growth factor receptor-2 and of its co-receptor neuropilin-1 in human vascular endothelial cells. J. Biol. Chem. 1998, 273, 22128-22135.

85. Schramek, H.; Sarközi, R.; Lauterberg, C.; Kronbichler, A.; Pirklbauer, M.; Albrecht, R.; Noppert, S.J.; Perco, P.; Rudnicki, M.; Strutz, F.M.; Mayer, G. Neuropilin-1 and neuropilin-2 are differentially expressed in human proteinuric nephropathies and cytokine-stimulated proximal tubular cells. Lab. Invest. 2009, 89, 1304-1316.

86. Neufeld, G.; Kessler, O. The semaphorins: Versatile regulators of tumour progression and tumour angiogenesis. Nat. Rev. Cancer 2008, 8, 632-645.

87. Gherardi, E.; Love, C.A.; Esnouf, R.M.; Jones, E.Y. The sema domain. Curr. Opin. Struct. Biol. 2004, 14, 669-678.

88. Capparuccia, L.; Tamagnone, L. Semaphorin signaling in cancer cells and in cells of the tumor microenvironment - two sides of a coin. J. Cell Sci. 2009, 122, 1723-1736.

89. Basile, J.R.; Holmbeck, K.; Bugge, T.H.; Gutkind, J.S. MT1-MMP controls tumor-induced angiogenesis through the release of semaphorin 4D. J. Biol. Chem. 2007, 282, 6899-6905. 
90. Winberg, M.L.; Noordermeer, J.N,; Tamagnone, L.; Comoglio, P.M.; Spriggs, M.K.; Tessier-Lavigne, M.; Goodman, C.S. Plexin A is a neuronal semaphorin receptor that controls axon guidance. Cell 1998, 95, 903-916.

91. Takahashi, T.; Fournier, A.; Nakamura, F.; Wang, L.H.; Murakami, Y.; Kalb, R.G.; Fujisawa, H.; Strittmatter, S.M. Plexin-neuropilin-1 complexes form functional semaphorin-3A receptors. Cell 1999, 99, 59-69.

92. Rohm, B.; Ottemeyer, A.; Lohrum, M.; Püschel, A.W. Plexin/neuropilin complexes mediate repulsion by the axonal guidance signal semaphorin 3A. Mech. Dev. 2000, 93, 95-104.

93. Fazzari, P.; Penachioni, J.; Gianola, S.; Rossi, F.; Eickholt, B.J.; Maina, F.; Alexopoulou, L.; Sottile, A.; Comoglio, P.M.; Flavell, R.A.; Tamagnone, L. Plexin-B1 plays a redundant role during mouse development and in tumour angiogenesis. BMC Dev. Biol. 2007, 7, 55.

94. Rieger, J.; Wick, W.; Weller, M. Human malignant glioma cells express semaphorins and their receptors, neuropilins and plexins. Glia 2003, 42, 379-389.

95. Rohm, B.; Rahim, B.; Kleiber, B.; Hovatta, I.; Püschel, A.W. The semaphorin 3A receptor may directly regulate the activity of small GTPases. FEBS Lett. 2000, 486, 68-72.

96. Vikis, H.G.; Li, W.; He, Z.; Guan, K.L. The semaphorin receptor plexin-B1 specifically interacts with active Rac in a ligand-dependent manner. Proc. Natl. Acad. Sci. USA 2000, 97, 12457-12462.

97. Driessens, M.H.; Hu, H.; Nobes, C.D.; Self, A.; Jordens, I.; Goodman, C.S.; Hall, A. Plexin-B semaphorin receptors interact directly with active Rac and regulate the actin cytoskeleton by activating Rho. Curr. Biol. 2001, 11, 339-344.

98. Aurandt, J.; Vikis, H.G.; Gutkind, J.S.; Ahn, N.; Guan, K.L. The semaphorin receptor plexin-B1 signals through a direct interaction with the Rho-specific nucleotide exchange factor, LARG. Proc. Natl. Acad. Sci. USA 2002, 99, 12085-12090.

99. Perrot, V.; Vázquez-Prado, J.; Gutkind, J.S.; Plexin B regulates Rho through the guanine nucleotide exchange factors leukemia-associated Rho GEF (LARG) and PDZ-RhoGEF. J. Biol. Chem. 2002, 277, 43115-43120.

100. Swiercz, J.M.; Kuner, R.; Behrens, J.; Offermanns, S. Plexin-B1 directly interacts with PDZ-RhoGEF/LARG to regulate RhoA and growth cone morphology. Neuron 2002 35, 51-63.

101. Cai, H.B.; Reed, R.R. Cloning and characterization of neuropilin-1 interacting protein: A PSD-95/Dlg/ZO-1 domain-containing protein that interacts with the cytoplasmic domain of neuropilin-1. J. Neurosci. 1999, 19, 6519-6527.

102. Roche, J.; Boldog, F.; Robinson, M.; Robinson, L.; Varella-Garcia, M.; Swanton, B.; Waggoner, B.; Fishel, R.; Franklin, W.; Gemmill, R.; Drabkin, H. Distinct 3p21.3 deletions in lung cancer, analysis of deleted genes and identification of a new human semaphorin. Oncogene 1996, 12, 1289-1297.

103. Xiang, R.H.; Hensel, C.H.; Garcia, D.K.; Carlson, H.C.; Kok, K.; Daly, M.C.; Kerbacher, K.; van den Berg, A.; Veldhuis, P.; Buys, C.H.; Naylor, S.L. Isolation of the human semaphorin III/F gene (SEMA3F) at chromosome 3p21, a region deleted in lung cancer. Genomics 1996, 32, 39-48.

104. Joseph, D.; Ho, S.M.; Syed, V. Hormonal regulation and distinct functions of semaphorin-3B and semaphorin-3F in ovarian cancer. Mol. Cancer Ther. 2010, 9, 499-509. 
105. Burbee, D.G.; Forgacs, E.; Zöchbauer-Müller, S.; Shivakumar, L.; Fong, K.; Gao, B.; Randle, D.; Kondo, M.; Virmani, A.; Bader, S.; et al. Epigenetic inactivation of RASSF1A in lung and breast cancers and malignant phenotype suppression. J. Nat. Cancer Inst. 2001, 93, 691-699.

106. Dammann, R.; Li, C.; Yoon, J.H.; Chin, P.L.; Bates, S.; Pfeifer, G.P. Epigenetic inactivation of a RAS association domain family protein from the lung tumour suppressor locus $3 \mathrm{p} 21.3$. Nat. Genet. 2000, 25, 315-319.

107. Kuroki, T.; Trapasso, F.; Yendamuri, S.; Matsuyama, A.; Alder, H.; Williams, N.N.; Kaiser, L.R.; Croce, C.M. Allelic loss on chromosome 3p21.3 and promoter hypermethylation of semaphorin 3B in non-small cell lung cancer. Cancer Res. 2003, 63, 3352-3355.

108. Ito, M.; Ito, G.; Kondo, M.; Uchiyama, M.; Fukui, T.; Mori, S.; Yoshioka, H.; Ueda, Y.; Shimokata, K.; Sekido, Y. Frequent inactivation of RASSF1A, BLU, and SEMA3B on 3p21.3 by promoter hypermethylation and allele loss in non-small cell lung cancer. Cancer Lett. 2005, 225, 131-139.

109. Bagnard, D.; Vaillant, C.; Khuth, S.T.; Dufay, N.; Lohrum, M.; Puschel, A.W.; Belin, M.F.; Bolz, J.; Thomasset, N. Semaphorin 3A-vascular endothelial growth factor-165 balance mediates migration and apoptosis of neural progenitor cells by the recruitment of shared receptor. J. Neurosci. 2001, 21, 3332-3341.

110. Guttmann-Raviv, N.; Shraga-Heled, N.; Varshavsky, A.; Guimaraes-Sternberg, C.; Kessler, O.; Neufeld, G. Semaphorin-3A and semaphorin-3F work together to repel endothelial cells and to inhibit their survival by induction of apoptosis. J. Biol. Chem. 2007, 282, 26294-26305.

111. Moretti, S.; Procopio, A.; Lazzarini, R.; Rippo, M.R.; Testa, R.; Marra, M.; Tamagnone, L.; Catalano, A. Semaphorin3A signaling controls Fas (CD95)-mediated apoptosis by promoting Fas translocation into lipid rafts. Blood 2008, 111, 2290-2299.

112. Kigel, B.; Varshavsky, A.; Kessler, O.; Neufeld, G. Successful inhibition of tumor development by specific class-3 semaphorins is associated with expression of appropriate semaphorin receptors by tumor cells. PLoS One 2008, 3, e3287.

113. Maione, F.; Molla, F.; Meda, C.; Latini, R.; Zentilin, L.; Giacca, M.; Seano, G.; Serini, G.; Bussolino, F.; Giraudo, E. Semaphorin 3A is an endogenous angiogenesis inhibitor that blocks tumor growth and normalizes tumor vasculature in transgenic mouse models. J. Clin. Invest. 2009, 119, 3356-3372.

114. Casazza, A.; Fu, X.; Johansson, I.; Capparuccia, L.; Andersson, F.; Giustacchini, A.; Squadrito, M.L.; Venneri, M.A.; Mazzone, M.; Larsson, E.; et al. Systemic and targeted delivery of semaphorin 3A inhibits tumor angiogenesis and progression in mouse tumor models. Arterioscler. Thromb. Vasc. Biol. 2011, doi: 10.1161/ATVBAHA.110.211920.

115. Tse, C.; Xiang, R.H.; Bracht, T.; Naylor, S.L. Human Semaphorin 3B (SEMA3B) located at chromosome 3p21.3 suppresses tumor formation in an adenocarcinoma cell line. Cancer Res. 2002, 62, 542-546.

116. Castro-Rivera, E.; Ran, S.; Thorpe, P.; Minna, J.D. Semaphorin 3B (SEMA3B) induces apoptosis in lung and breast cancer, whereas VEGF165 antagonizes this effect. Proc. Natl. Acad. Sci. USA 2004, 101, 11432-11437. 
117. Castro-Rivera, E.; Ran, S.; Brekken, R.A.; Minna, J.D. Semaphorin 3B inhibits the phosphatidylinositol 3-kinase/Akt pathway through neuropilin-1 in lung and breast cancer cells. Cancer Res. 2008, 68, 8295-8303.

118. Rolny, C.; Capparuccia, L.; Casazza, A.; Mazzone, M.; Vallario, A.; Cignetti, A.; Medico, E.; Carmeliet, P.; Comoglio, P.M.; Tamagnone, L. The tumor suppressor semaphorin 3B triggers a prometastatic program mediated by interleukin 8 and the tumor microenvironment. J. Exp. Med. 2008, 205, 1155-1171.

119. Brambilla, E.; Constantin, B.; Drabkin, H.; Roche, J. Semaphorin SEMA3F localization in malignant human lung and cell lines: A suggested role in cell adhesion and cell migration. Am. J. Pathol. 2000, 156, 939-950.

120.Xiang, R.; Davalos, A.R.; Hensel, C.H.; Zhou, X.J.; Tse, C.; Naylor, S.L. Semaphorin 3F gene from human 3p21.3 suppresses tumor formation in nude mice. Cancer Res. 2002, 62, 2637-2643.

121. Kusy, S.; Nasarre, P.; Chan, D.; Potiron, V.; Meyronet, D.; Gemmill, R.M.; Constantin, B.; Drabkin, H.A.; Roche, J. Selective suppression of in vivo tumorigenicity by semaphorin SEMA3F in lung cancer cells. Neoplasia 2005, 7, 457-465.

122. Kessler, O.; Shraga-Heled, N.; Lange, T. Semaphorin-3F is an inhibitor of tumor angiogenesis. Cancer Res. 2004, 64, 1008-1015.

123. Bielenberg, D.R.; Hida, Y.; Shimizu, A.; Kaipainen, A.; Kreuter, M.; Choi, K.C.; Klagsbrun, M. Semaphorin 3F, a chemorepulsant for endothelial cells, induces a poorly vascularized, encapsulated, nonmetastatic tumor phenotype. J. Clin. Invest. 2004, 114, 1260-1268.

124. Chabbert-de Ponnat, I.; Buffard, V.; Leroy, K.; Bagot, M.; Bensussan, A.; Wolkenstein, P.; Marie-Cardine, A. Antiproliferative effect of semaphorin 3F on human melanoma cell lines. J. Invest. Dermatol. 2006, 126, 2343-2345.

125. Nasarre, P.; Kusy, S.; Constantin, B. Semaphorin SEMA3F has a repulsing activity on breast cancer cells and inhibits E-cadherinmediated cell adhesion. Neoplasia 2005, 7, 180-189.

126. Christensen, C.; Ambartsumian, N.; Gilestro, G.; Thomsen, B.; Comoglio, P.; Tamagnone, L.; Guldberg, P.; Lukanidin, E. Proteolytic processing converts the repelling signal Sema3E into an inducer of invasive growth and lung metastasis. Cancer Res. 2005, 65, 6167-6177.

127.Pan, H.; Wanami, L.S.; Dissanayake, T.R.; Bachelder, R.E. Autocrine semaphorin3A stimulates alpha2 beta1 integrin expression/function in breast tumor cells. Breast Cancer Res. Treat. 2009, 118, 197-205.

128. Nasarre, P.; Constantin, B.; Rouhaud, L. Semaphorin SEMA3F and VEGF have opposing effects on cell attachment and spreading. Neoplasia 2003, 5, 83-92.

129. Gluzman-Poltorak, Z.; Cohen, T.; Shibuya, M.; Neufeld, G. Vascular endothelial growth factor receptor-1 and neuropilin-2 form complexes. J. Biol. Chem. 2001, 276, 18688-18694.

130. Favier, B.; Alam, A.; Barron, P.; Bonnin, J.; Laboudie, P.; Fons, P.; Mandron, M.; Herault, J.P.; Neufeld, G.; Savi, P. Neuropilin-2 interacts with VEGFR-2 and VEGFR-3 and promotes human endothelial cell survival and migration. Blood 2006, 108, 1243-1250.

131. Caunt, M.; Mak, J.; Liang, W.C.; Stawicki, S.; Pan, Q.; Tong, R.K.; Kowalski, J.; Ho, C.; Reslan, H.B.; Ross, J.; et al. Blocking neuropilin-2 function inhibits tumor cell metastasis. Cancer Cell 2008, 13, 331-342. 
132.Xu, Y.; Yuan, L.; Mak, J.; Pardanaud, L.; Caunt, M.; Kasman, I.; Larrivée, B.; Del Toro, R.; Suchting, S.; Medvinsky, A.; et al. Neuropilin-2 mediates VEGF-C-induced lymphatic sprouting together with VEGFR3. J. Cell. Biol. 2010, 188, 115-130.

133. Tang, X.L.; Sun, J.F.; Wang, X.Y.; Du, L.L.; Liu, P. Blocking neuropilin-2 enhances corneal allograft survival by selectively inhibiting lymphangiogenesis on vascularized beds. Mol. Vis. 2010, 16, 2354-2361.

134. Fukasawa, M.; Matsushita, A.; Korc, M. Neuropilin-1 interacts with integrin beta1 and modulates pancreatic cancer cell growth, survival and invasion. Cancer Biol. Ther. 2007, 6, 1173-1180.

135. Valdembri, D.; Caswell, P.T.; Anderson, K.I.; Schwarz, J.P.; König, I.; Astanina, E.; Caccavari, F.; Norman, J.C.; Humphries, M.J.; Bussolino, F.; Serini, G. Neuropilin-1/GIPC1 signaling regulates alpha5beta1 integrin traffic and function in endothelial cells. PLoS Biol. 2009, 7, e1000025.

136. Robinson, S.D.; Reynolds, L.E.; Kostourou, V.; Reynolds, A.R.; da Silva, R.G.; Tavora, B.; Baker, M.; Marshall, J.F.; Hodivala-Dilke, K.M. Alphav beta3 integrin limits the contribution of neuropilin-1 to vascular endothelial growth factor-induced angiogenesis. J. Biol. Chem. 2009, 284, 33966-33981.

137.Hu, B.; Guo, P.; Bar-Joseph, I.; Imanishi, Y.; Jarzynka, M.J.; Bogler, O.; Mikkelsen, T.; Hirose, T.; Nishikawa, R.; Cheng, S.Y. Neuropilin-1 promotes human glioma progression through potentiating the activity of the HGF/SF autocrine pathway. Oncogene 2007, 26, 5577-5586.

138. Matsushita, A.; Götze, T.; Korc, M. Hepatocyte growth factor-mediated cell invasion in pancreatic cancer cells is dependent on neuropilin-1. Cancer Res. 2007, 67, 10309-10316.

139. Glinka, Y.; Prud'homme, G.J. Neuropilin-1 is a receptor for transforming growth factor beta-1, activates its latent form, and promotes regulatory T cell activity. J. Leukoc. Biol. 2008, 84, 302-310.

140. Glinka, Y.; Stoilova, S.; Mohammed, N.; Prud'homme, G.J. Neuropilin-1 exerts coreceptor function for TGF-beta-1 on the membrane of cancer cells and enhances responses to both latent and active TGF-beta. Carcinogenesis 2010, 32, 613-621.

141.Cao, S.; Yaqoob, U.; Das, A.; Shergill, U.; Jagavelu, K.; Huebert, R.C.; Routray, C.; Abdelmoneim, S.; Vasdev, M.; Leof, E.; et al. Neuropilin-1 promotes cirrhosis of the rodent and human liver by enhancing PDGF/TGF-beta signaling in hepatic stellate cells. J. Clin. Invest. 2010, 120, 2379-2394.

142.Cao, Y.; Szabolcs, A.; Dutta, S.K.; Yaqoob, U.; Jagavelu, K.; Wang, L.; Leof, E.B.; Urrutia, R.A.; Shah, V.H.; Mukhopadhyay, D. Neuropilin-1 mediates divergent R-Smad signaling and the myofibroblast phenotype. J. Biol. Chem. 2010, 285, 31840-31848.

143. Grandclement, C.; Bedel, R.; Kantelip, B.; Bouard, A.; Mougey, V.; Klagsbrun, M.; Ferrand, C.; Tiberghien, P.; Pivot, X.B.; Borg, C. Neuropilin-2 and epithelial to mesenchymal transition in colorectal cancer cells. J. Clin. Oncol. 2010, 28, Abstract 10628.

144. Guarino, M. Epithelial-mesenchymal transition and tumour invasion. Int. J. Biochem. Cell Biol. 2007, 39, 2153-2160.

145. Bergé, M.; Bonnin, P.; Sulpice, E.; Vilar, J.; Allanic, D.; Silvestre, J.S.; Lévy, B.I.; Tucker, G.C.; Tobelem, G.; Merkulova-Rainon, T. Small interfering RNAs induce target-independent inhibition of tumor growth and vasculature remodeling in a mouse model of hepatocellular carcinoma. Am. J. Pathol. 2010, 177, 3192-3201. 
146. Raskopf, E.; Vogt, A.; Standop, J.; Sauerbruch, T.; Schmitz, V. Inhibition of neuropilin-1 by RNA-interference and its angiostatic potential in the treatment of hepatocellular carcinoma. Z Gastroenterol 2010, 48, 21-27.

147.Hong, T.M.; Chen, Y.L.; Wu, Y.Y.; Yuan, A.; Chao, Y.C.; Chung, Y.C.; Wu, M.H.; Yang, S.C.; Pan, S.H.; Shih, J.Y.; Chan, W.K.; Yang, P.C. Targeting neuropilin 1 as an antitumor strategy in lung cancer. Clin. Cancer Res. 2007, 13, 4759-4768.

148. Schuch, G.; Machluf, M.; Bartsch, G., Jr.; Nomi, M.; Richard, H.; Atala, A.; Soker, S. In vivo administration of vascular endothelial growth factor (VEGF) and its antagonist, soluble neuropilin-1, predicts a role of VEGF in the progression of acute myeloid leukemia in vivo. Blood 2002, 100, 4622-4628.

149. Geretti, E.; Van Meeteren, L.A.; Shimizu, A.; Dudley, A.C.; Claesson-Welsh, L.; Klagsbrun, M. A mutated soluble neuropilin-2 B domain antagonizes vascular endothelial growth factor bioactivity and inhibits tumor progression. Mol. Cancer Res. 2010, 8, 1063-1073.

150. Sugahara, K.N.; Teesalu, T.; Karmali, P.P.; Kotamraju, V.R.; Agemy, L.; Girard, O.M.; Hanahan, D.; Mattrey, R.F.; Ruoslahti, E. Tissue-penetrating delivery of compounds and nanoparticles into tumors. Cancer Cell 2009, 16, 510-520.

151. Sugahara, K.N.; Teesalu, T.; Karmali, P.P.; Kotamraju, V.R.; Agemy, L.; Greenwald, D.R.; Ruoslahti, E. Coadministration of a tumor-penetrating peptide enhances the efficacy of cancer drugs. Science 2010, 328, 1031-1035.

152. Teesalu, T.; Sugahara, K.N.; Kotamraju, V.R.; Ruoslahti, E. C-end rule peptides mediate neuropilin-1-dependent cell, vascular, and tissue penetration. Proc. Natl. Acad. Sci. USA 2009, 106, 16157-16162.

153. Jarvis, A.; Allerston, C.K.; Jia, H.; Herzog, B.; Garza-Garcia, A.; Winfield, N.; Ellard, K.; Aqil, R.; Lynch, R.; Chapman, C.; et al. Small molecule inhibitors of the neuropilin-1 vascular endothelial growth factor A (VEGF-A) interaction. J. Med. Chem. 2010, 53, 2215-2226.

154. Karjalainen, K.; Jaalouk, D.E.; Bueso-Ramos, C.E.; Zurita, A.J.; Kuniyasu, A.; Eckhardt, B.L.; Marini, F.C.; Lichtiger, B.; O’Brien, S.; Kantarjian, H.M.; et al. Targeting neuropilin-1 in human leukemia and lymphoma. Blood 2011, 117, 920-927.

155. Nasarre, C.; Roth, M.; Jacob, L.; Roth, L.; Koncina, E.; Thien, A.; Labourdette, G.; Poulet, P.; Hubert, P.; Crémel, G.; Roussel, G.; Aunis, D.; Bagnard, D. Peptide-based interference of the transmembrane domain of neuropilin-1 inhibits glioma growth in vivo. Oncogene 2010, 29, 2381-2392.

156.Liang, W.C.; Dennis, M.S.; Stawicki, S.; Chanthery, Y.; Pan, Q.; Chen, Y.; Eigenbrot, C.; Yin, J.; Koch, A.W.; Wu, X.; et al. Function blocking antibodies to neuropilin-1 generated from a designed human synthetic antibody phage library. J. Mol. Biol. 2007, 366, 815-829.

157. Pan, Q.; Chanthery, Y.; Liang, W.C.; Stawicki, S.; Mak, J.; Rathore, N.; Tong, R.K.; Kowalski, J.; Yee, S.F.; Pacheco, G.; et al. Blocking neuropilin-1 function has an additive effect with anti-VEGF to inhibit tumor growth. Cancer Cell 2007, 11, 53-67.

158. http://clinicaltrials.gov/ct2/show/NCT00747734?term=neuropilin\&rank=1/ (accessed 2 January 2011).

159. Basile, J.R.; Castilho, R.M.; Williams, V.P.; Gutkind, J.S. Semaphorin 4D provides a link between axon guidance processes and tumor-induced angiogenesis. Proc. Natl. Acad. Sci. USA 2006, 103, 9017-9022. 
160. Conrotto, P.; Valdembri, D.; Corso, S.; Serini, G.; Tamagnone, L.; Comoglio, P.M.; Bussolino, F.; Giordano, S. Sema4D induces angiogenesis through Met recruitment by Plexin B1. Blood 2005, 105, 4321-4329.

161. http://clinicaltrials.gov/ct2/show/NCT01313065?term=semaphorin\&rank=1/ (accessed 2 January 2011).

(C) 2011 by the authors; licensee MDPI, Basel, Switzerland. This article is an open access article distributed under the terms and conditions of the Creative Commons Attribution license (http://creativecommons.org/licenses/by/3.0/). 